\title{
EFFECT OF NUTRIENT LOADING ON BIOGEOCHEMICAL PROCESSES IN TROPICAL TIDAL CREEKS
}

Jodie Smith $^{1 *}$, Michele A. Burford ${ }^{2}$, Andrew T. Revill ${ }^{3}$, Ralf R. Haese ${ }^{1}$, Julia Fortune ${ }^{4}$

${ }^{1}$ Tropical Rivers and Coastal Knowledge Program, Geoscience Australia, Canberra, Australia

2 Tropical Rivers and Coastal Knowledge Program, Australian Rivers Institute, Griffith University, Brisbane, Australia

${ }^{3}$ Tropical Rivers and Coastal Knowledge Program, CSIRO Marine and Atmospheric Research, Hobart, Australia

${ }^{4}$ Tropical Rivers and Coastal Knowledge Program, Northern Territory Department of Natural Resources, Environment, the Arts and Sport, Darwin, Australia

*Corresponding author: jodie.smith@ga.gov.au; GPO Box 378, Canberra, ACT, 2601, Australia. Ph: +61 26249 9487. Fax: +61 262499961

Keywords

benthic fluxes, coupled nitrification-denitrification, hypoxia, nutrient loads, primary production 


\section{Abstract}

The effect of increased nutrient loads on biogeochemical processes in macrotidal, mangrove-lined creeks was studied in tropical Darwin Harbour, Australia. This study uses an integrative approach involving multiple benthic and pelagic processes as measures of ecosystem function, and provides a comparison of these processes in three tidal creeks receiving different loads of treated sewage effluent. There were significant differences in process rates between Buffalo Creek (hypereutrophic), which receives the largest sewage loads; Myrmidon Creek (oligotrophic-mesotrophic) which receives smaller sewage inputs; and Reference Creek (oligotrophic) which is comparatively pristine. Benthic nutrient fluxes and denitrification were more than an order of magnitude higher and lower, respectively, in Buffalo Creek and denitrification efficiency was less than $10 \%$. Pelagic primary production rates were also much higher in Buffalo Creek but respiration exceeded primary production resulting in severe drawdown of $\mathrm{O}_{2}$ concentrations at night. Hypoxic conditions released oxide-bound phosphorus and inhibited coupled nitrification-denitrification, enhancing benthic nitrogen and phosphorus fluxes, leading to a build-up of excess nutrients in the water column. Poor water quality in Buffalo Creek was exacerbated by limited tidal flushing imposed by a narrow meandering channel and sandbar across the mouth. In contrast to Buffalo Creek, the effect of the sewage load in Myrmidon Creek was confined to the water column, and the impact was temporary and highly localized. This is attributed to the effective flushing of the sewage plume with each tidal cycle. Denitrification rates in Myrmidon and Reference Creeks were high (up to $6.83 \mathrm{mmol} \mathrm{N} \mathrm{m} \mathrm{d}^{-1}$ ) and denitrification efficiency was approximately $90 \%$. This study has identified denitrification, benthic nutrient fluxes and pelagic primary production as the biogeochemical processes most affected by nutrient loading in these 
tidal creek systems. Physical process play a key role and the combined influence of nutrient loading and poor tidal flushing can have serious consequences for ecosystem functioning. 


\section{Introduction}

Estuaries are complex, open systems that often experience large inputs of organic matter and inorganic nutrients from land. Biogeochemical processes subsequently determine the extent of nutrient transformations, retention and export to the ocean. Tropical estuaries are among the most biogeochemically active regions in the biosphere, but the processes are complex due to factors such as highly variable hydrodynamics, particularly in macrotidal systems (e.g. Wolanski et al. 1980), large organic matter inputs from fringing mangroves (e.g. Dittmar et al. 2006), large monsoonal freshwater inputs (e.g. Sarma et al. 2009), as well as heavy bioturbation in intertidal sediments (e.g. Pratihary et al. 2009).

Changes to the structure and function of estuaries due to increased anthropogenic nutrient loadings arising from such diverse sources as urban and rural run-off, sewage discharges and aquaculture are well known (Nixon 1995; Herbert 1999; Cloern 2001; Clarke et al. 2006). The increased input of nutrients to shallow marine environments, including estuaries, and the accompanying stimulation of primary production enhance organic matter supply to sediments, increasing benthic metabolism and resulting in greater nutrient release and rates of oxygen consumption (Richardson \& Jørgensen 1996; Herbert 1999; Cloern 2001). Hypoxia is a common effect of nutrient loading in coastal marine ecosystems and the effects are most severe in areas such as shallow embayments or where tidal flushing is limited (Herbert 1999; Diaz \& Rosenberg 2008). Hypoxia influences biogeochemical processes that control nutrient concentrations in the water column (Conley et al. 2009) and can lead to dead zones which have serious consequences for ecosystem structure and functioning (Diaz \& 
Rosenberg 2008). Thus, increased nutrient loads can have important consequences for the structure of estuarine communities, aquatic food webs and estuarine water quality.

Nutrient loading is considered to be the most widespread problem in estuaries around the world and is likely to increase in the future (Howarth et al. 2002). The impact is expected to be greater in the tropics than at higher latitudes (Downing et al. 1999) and on a global scale, tropical regions such as southeast Asia are particularly vulnerable in terms of ecosystem alteration due to anthropogenic nutrient loading (Mackenzie et al. 2002; Jennerjahn et al. 2004; Halpern et al. 2008). The effects of altered nutrient cycling in tropical ecosystems can be understood most easily in the context of nutrient dynamics in undisturbed or minimally disturbed tropical ecosystems, however, nutrient processing in tropical estuaries, in general, is poorly studied relative to temperate environments (Downing et al. 1999; Bianchi 2007) and there are even fewer studies comparing biogeochemical cycles in disturbed and undisturbed tropical systems (Trott et al. 2004; Kristensen et al. 2008). Additionally, these studies are often limited in the suite of processes measured, with much of the information available tending to be focused on individual processes (Boynton et al. 2008). This study uses an integrative approach involving multiple benthic and pelagic processes as measures of ecosystem function, and provides a comparison of these processes across a gradient of nutrient loads in a tropical estuary. This study also provides the first reported measurements of denitrification in Darwin Harbour.

The aim of this study was to determine the effect of increased nutrient loads on multiple biogeochemical processes within tropical tidal creeks in Darwin Harbour and to identify which processes are most effective in determining eutrophication impacts in tidal creeks. Darwin Harbour is an N-limited system and is subject to 
anthropogenic nutrient inputs from urban and rural-runoff, as well as treated sewage effluent. Impacts on water quality in Darwin Harbour as a result of seasonal and point source nutrient inputs have been reported previously (e.g. McKinnon et al. 2006; Burford et al. 2008) and fish kills have occurred in tidal creeks receiving sewage effluent. There is potential for more severe impacts on water quality and overall ecological health in the future due to increasing population and land development. Indeed, Darwin has the most rapid population growth in Australia. Considering the rapid changes occurring in tropical estuaries as a result of nutrient enrichment associated with point and non-point sources, understanding the functioning of these systems and their interactions is important to be able to correctly assess the health of estuaries (Bouillon \& Connolly 2009).

\section{Materials and Methods}

\section{Study Area}

The study was performed in three tidal creeks in Darwin Harbour in northern Australia (Fig. 1). Darwin Harbour is a large macrotidal estuary with a maximum tidal range of $7.8 \mathrm{~m}$. The harbour is fringed by dense mangroves and during low tide, extensive intertidal mudflats are exposed (Fig. 1). The region is influenced by a tropical monsoonal climate characterized by high year-round temperatures and a highly seasonal rainfall pattern, with over $1300 \mathrm{~mm}$ falling during the monsoon season (December to March). River flow into the harbour is also highly seasonal with maximum flow between January and March and a cessation in flow between May and July. Although the harbour experiences a distinct wet season, the catchment is relatively small and wet season runoff has relatively little impact over the whole harbour. Most of the freshwater runoff occurs in the form of a few discrete flood 
events during which the upper reaches of the harbour may become fully fresh. However, there is no marked river plume exiting the harbour and salinity remains almost constant at the mouth of the harbour throughout the year, implying that freshwater runoff is strongly diluted by the time it reaches the mouth (Williams et al. 2006).

The majority of nutrients that enter the harbour are imported from the ocean and are typically in the particulate or organic form (Burford et al. 2008). Nutrients also enter the harbour from the surrounding catchment and include both diffuse sources, such as urban and rural runoff, and point sources such as treated sewage effluent which is discharged into both the main body of the harbour and several tidal creeks on the fringes. Overall, the harbour is considered relatively pristine (McKinnon et al. 2006).

\section{Field Stations and Sampling}

Sediment and water column sampling was carried out at two sites in three tidal creeks; an unnamed creek (herein referred to as Reference Creek, RC) and Myrmidon Creek (MC) in East Arm of Darwin Harbour, and Buffalo Creek (BC) in Shoal Bay (Fig. 1). $\mathrm{RC}$ and MC have similar geomorphology with predominantly straight channels, widening downstream (Fig. 1a \& b). At low tide, intertidal mudflats, several metres wide, are exposed along the length of the creeks. The upper reaches of the creeks may be fully drained at low tide, however the creeks contain water at all times. BC consists of a long, narrow channel with large meander bends at the downstream end (Fig. 1c). Upstream the channel becomes even narrower and meanders through dense, overhanging mangroves. Intertidal mudflats occur on the meander bends and along sections of the main channel. A large intertidal sand bar across the mouth inhibits tidal movement to a significant degree. 
$\mathrm{RC}$ is considered to be near-pristine with no known impact from urbanization or land development (Woodroffe et al. 1988). MC and BC receive sewage effluent from sewage treatment plants (STP) which use waste stabilization ponds to remove organic

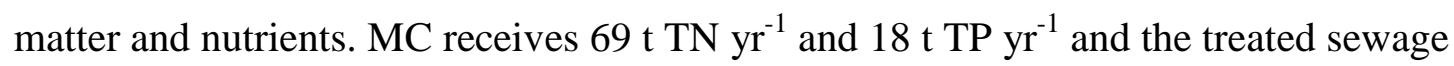
effluent is discharged into the mangroves close to site $\mathrm{MC1}$ (Fig. 1b). BC receives 79

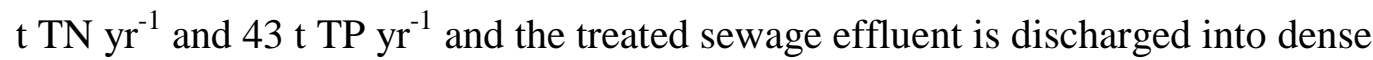
mangroves at the upstream end of the creek (Fig. 1c). While the sewage loads entering $\mathrm{BC}$ and $\mathrm{MC}$ are similar, the dimensions and hence water volume, are much lower in $\mathrm{BC}$ than in $\mathrm{MC}$. The sewage discharge is gravity-fed, i.e. there is only discharge when the tide level is below the outflow pipe. At high tide, flow is stopped.

This study was conducted during 2007-8 over 3 sampling periods. Rapidly changing tidal conditions limited boat access to many areas of the harbour and the sampling sites and times were chosen based on those areas that were accessible in practice. Therefore, we have to assume that the tidal creeks and sites within each creek were representative. Each sampling period lasted 5-6 days in between spring and neap tides during the 2-week tidal cycle. Surveys during the wet and dry season were undertaken to differentiate land runoff effects from sewage effluent inputs. Sewage effluent inputs are relatively constant all year round. RC and MC were sampled in the dry and wet seasons (October 2007 and March 2008). BC was sampled at the end of the dry season (early December 2008). We have assumed that our sampling periods were representative of the seasonal cycles and we have no reason to believe environmental conditions (e.g. STP discharge, water quality conditions) would be significantly different at other times during each season. 


\section{Water column physico-chemical conditions}

Water sampling was conducted at least twice (typically on consecutive days) at each site in $\mathrm{MC}$ and $\mathrm{RC}$ during the ebb tide. In $\mathrm{BC}$, initial field observations indicated rapidly changing physico-chemical conditions during the tidal cycle so water sampling was conducted every 1-2 hrs during the benthic chamber deployments and additional sampling conducted on consecutive days.

Water column parameters (temperature, salinity, dissolved oxygen) were recorded at each site with a YSI sonde (6000XLM). Photosynthetically active radiation (PAR) was measured during the middle of the day at water depth intervals of $0.5-1 \mathrm{~m}$ using a LI-COR light meter with a $4 \pi$ quantum underwater sensor (LI-192) and this data used to calculate the euphotic depth $\left(\mathrm{Z}_{\mathrm{eu}}\right)$. Surface water samples were collected in $1 \mathrm{~L}$ bottles. Total suspended solids (TSS) was determined by filtering water samples using pre-weighed membrane filters $(0.45 \mu \mathrm{m}$, Millipore $)$, drying at $60^{\circ} \mathrm{C}$ and re-weighing. Sub-samples were filtered $(0.45 \mu \mathrm{m}$, Bonnet $)$ into $30 \mathrm{~mL}$ tubes and frozen until analysis for nutrients. Samples for chlorophyll $a$ (chl $a$ ) were collected by filtering water from just below the surface through GF/F filters (Whatman) using a manual pump. The filters were placed in cryotubes and stored in liquid nitrogen until analysis.

During the December 2008 field campaign in MC, continuous measurements of physico-chemical parameters were made using a YSI sonde over a $5 \mathrm{hr}$ period from high tide to low tide to measure the treated sewage effluent plume as it emerged from the mangroves. Surface water samples were collected at approximately $1 \mathrm{hr}$ intervals and were measured for TSS, total nutrients and chl $a$. 
Water column primary production was measured using ${ }^{13} \mathrm{C}$-uptake incubations. Water samples collected just below the surface were stored in buckets during transport to the field laboratory. $500 \mathrm{ml}$ acid-washed polycarbonate bottles were filled with water collected from each site. Triplicate bottles from each bucket were incubated at 0,5 , $14,25,50$ and $100 \%$ of surface light using shade bags of appropriate light attenuation. ${ }^{13} \mathrm{C}$-sodium bicarbonate was added to bottles to give a final enrichment of between 3 and $5 \%$ of the total bicarbonate concentration.

The bottles were incubated in a large tank with flowing water at ambient water temperature. Bottles were incubated on either side of local apparent noon (when the sun was highest in the sky) for 2 to $3 \mathrm{~h}$. Known volumes of water from the bottles were filtered onto precombusted glass fibre (Whatman GF/F) filters which were frozen until analysis. Hourly primary production rates were calculated as the change in carbon concentration at each light level. Maximum productivity $\left(\mathrm{P}_{\max }, \mathrm{mmol} \mathrm{C} \mathrm{m}{ }^{-3}\right.$ $\mathrm{h}^{-1}$ ) was estimated from the $100 \%$ light incubation. Daily depth-integrated net primary production (NPP) was calculated by integrating primary production rates through the water column based on the ${ }^{13} \mathrm{C}$-bicarbonate incubation and light data, based on a $10 \mathrm{~h}$ daylight period.

Maximum production and respiration were also measured by means of oxygen production and consumption, respectively. Surface water was collected and incubated in four (2 transparent, 2 opaque) gas-tight, $100 \mathrm{~mL}$ glass syringes (Hamilton). The syringes were incubated within the water column for 3 to $4 \mathrm{~h}$. Four samples were removed from each syringe during the incubation for $\mathrm{O}_{2}$ analysis, transferred into 12 ml gas-tight glass vials with glass stoppers, preserved with saturated $\mathrm{HgCl}_{2}$ and stored 
submerged just below ambient temperature in the dark until analysis. $\mathrm{P}_{\max }$ and respiration ( $\mathrm{mmol} \mathrm{O}_{2} \mathrm{~m}^{-3} \mathrm{~h}^{-1}$ ) were estimated as the change in oxygen concentration during light and dark incubations, respectively. Daily depth-integrated community respiration $\left(\mathrm{CR}, \mathrm{mmol} \mathrm{C} \mathrm{m}^{-2} \mathrm{~d}^{-1}\right)$ was calculated assuming that respiration rates were constant with depth and respiration rates converted to carbon units assuming a respiratory quotient (RQ) of 1 (Laws 1991). Gross primary production (GPP) was calculated as the sum of NPP and CR during a $10 \mathrm{~h}$ daylight period, and the productivity:respiration $(\mathrm{P}: \mathrm{R})$ ratio calculated as the ratio GPP:CR.

\section{Surface Sediments}

Sediment cores (6 cm dia.) were collected at each site using a push corer. Surface sediment (to $1 \mathrm{~cm}$ depth) from one core was transferred into clean glass jars and homogenized. Clean aluminium foil was placed between the lid and contents to minimize organic contamination. The samples were frozen until analysis for TOC, TN and stable isotope composition. Subsamples were taken for chl $a$ analysis and placed in cryo-vials in a liquid nitrogen dry shipper. Surface sediment from a second core was transferred to plastic vials and frozen for total phosphorus (TP) analysis. Porosity was determined on a subsample by weight difference between wet and dry sediment following freeze-drying.

\section{Sediment Primary Productivity}

Sediment cores $(4.5 \mathrm{~cm}$ dia.) were collected at each site for measurement of primary productivity in the sediment. Capped cores were transported with overlying water from the study site to the field laboratory. Primary productivity was measured at 0 , 10,50 and $100 \%$ of surface light using shade bags of appropriate light attenuation. 
${ }^{13} \mathrm{C}$-sodium bicarbonate was added to bottles to give a final enrichment of between 40 and $50 \%$ of the total bicarbonate concentration to the overlying water.

The cores were incubated in a large tank with flowing water at ambient water temperature around local apparent noon for 2 to $3 \mathrm{~h}$. The temperature was logged throughout the incubations. Cores were then kept in the dark until processed. The top $2 \mathrm{~cm}$ was sliced off each core and frozen until analysis.

\section{Benthic flux incubations}

Benthic chamber incubations were used to quantify the flux of dissolved inorganic nutrients $\left(f \mathrm{NH}_{4}{ }^{+}, f \mathrm{NO}_{\mathrm{x}}, f \mathrm{PO}_{4}{ }^{3-}, f \mathrm{SiO}_{4}\right)$ and dissolved gas $\left(f \mathrm{DO}, f \mathrm{DIC}, f \mathrm{~N}_{2}\right)$. Four manually operated benthic chambers ( 2 transparent, 2 opaque), as described by Haese et al. (2007), were deployed at each site. Self-logging probes (YSI-600XL) continuously measured temperature, salinity and oxygen concentration inside and outside of the chambers. The incubation began after manually closing the chamber lid. Five or six chamber-water samples with a volume of $100 \mathrm{~mL}$ were taken during an incubation period typically lasting 3 to $5 \mathrm{~h}$. Water samples for nutrient analysis were filtered immediately $(0.45 \mu \mathrm{m})$ into $30 \mathrm{~mL}$ tubes and frozen until analysis. Samples for DIC were filtered $(0.45 \mu \mathrm{m})$ into gas-tight vials ( $3 \mathrm{ml}$, Exetainer), preserved with saturated $\mathrm{HgCl}_{2}$ and stored in the dark until analysis. Samples for $\mathrm{N}_{2}$ were transferred into $12 \mathrm{ml}$ gas-tight vials with glass stoppers, preserved with saturated $\mathrm{HgCl}_{2}$ and stored submerged just below ambient temperature in the dark until analysis.

Benthic nutrient and gas fluxes were calculated from concentration changes over time, accounting for the incubated sediment surface area and water volume and corrected for the replenishment of sample volumes by ambient bottom water. During high tide, 
the light chambers were beyond the photic zone, and data collected during these periods were used in the calculation of dark fluxes. Only the linear proportion of the concentration versus incubation time curve was used in the flux calculations. Water incubated by benthic chambers never reached oxygen concentrations below $20 \%$ saturation, with the exception of $\mathrm{BC} 1$ where ambient water was at or below this level at the start of the incubation. Denitrification efficiency was calculated from the dissolved inorganic nitrogen fluxes:

$\mathrm{DE} \%=f \mathrm{~N}_{2} /\left(f \mathrm{~N}_{2}+f \mathrm{NH}_{4}+f \mathrm{NO}_{\mathrm{x}}\right) \times 100$

Benthic production $(\mathrm{P})$ and respiration $(\mathrm{R})$ were calculated as the change in carbon concentration during light and dark incubations, respectively. Gross primary production (GPP) was calculated as the sum of $\mathrm{P}$ and $\mathrm{R}$ during a $6 \mathrm{~h}$ light period, and the productivity:respiration ratio calculated as the ratio GPP:R.

\section{Analytical Methods}

Dissolved inorganic nutrients, $\mathrm{NH}_{4}{ }^{+}, \mathrm{NO}_{\mathrm{x}}, \mathrm{PO}_{4}{ }^{3-}$ and $\mathrm{SiO}_{4}$ from the filtered surface water and benthic chamber samples were analyzed by automated flow injection analysis (Lachat). Dissolved inorganic carbon (DIC) was analyzed on an infrared gas analyzer (LiCOR 7000). $\mathrm{N}_{2}$ from the benthic chamber samples and $\mathrm{O}_{2}$ from the surface water syringe incubations were measured using a membrane inlet mass

spectrometer (MIMS) (Kana et al. 1994). Filters from the ${ }^{13} \mathrm{C}$-uptake incubations were dried at $60^{\circ} \mathrm{C}$ for $24 \mathrm{~h}$ before being analyzed for ${ }^{13} \mathrm{C} /{ }^{12} \mathrm{C}$ ratio and $\%$ carbon on a mass spectrometer (GV Isoprime, Manchester UK). Sediment cores from benthic ${ }^{13} \mathrm{C}$ uptake incubations were analyzed in the same way following treatment with $6 \mathrm{~N}$ hydrochloric acid to remove carbonates. 
Chl $a$ was extracted from sediment and water column filters prior to analysis by high performance liquid chromatography following the procedures outlined in Cook et al. (2004) and Haese et al. (2007), respectively. Sediment samples for stable isotope analysis $\left(\delta^{13} \mathrm{C}\right.$ and $\left.\delta^{15} \mathrm{~N}\right)$ were processed and analyzed for $\delta^{13} \mathrm{C}$ and $\delta^{15} \mathrm{~N}$ as described in Cook et al. (2004). Results are presented in standard $\delta$ notation:

$$
\delta(\%)=\left[\frac{R_{\text {sample }}}{R_{\text {standard }}}-1\right]
$$

where $\mathrm{R}={ }^{13} \mathrm{C} /{ }^{12} \mathrm{C}$ or ${ }^{15} \mathrm{~N} /{ }^{14} \mathrm{~N}$. The standard for carbon is Vienna Pee Dee Belemnite (VPDB) while that for nitrogen is air. The reproducibility of the stable isotope measurements was $\pm 0.2 \%$ for carbon and $\pm 0.5 \%$ for nitrogen.

Sediment total P (TP) was determined by X-ray fluorescence using a Philips PW2404 $4 \mathrm{~kW}$ sequential spectrometer according to a modified version of Norrish and Hutton's (1969) method. The instrument was calibrated using United States Geological Survey (USGS) and South African Reference Material international standards. The reported precision was better than $5 \%$.

\section{Hydrodynamic Calculations}

A simple tidal prism model (Seabergh 2006) was used to estimate the exchange of water in the tidal creeks with marine water in the main body of the harbour, as this is the dominant influence on water quality (McKinnon et al. 2006). The tidal prism is computed as follows:

$$
p=2 * a(b) * A(b)
$$


Where $a(b)$ is the tidal amplitude or $1 / 2$ the tidal range and $A(b)$ is the water area. The exchange calculation is:

$$
T_{(d)}=\frac{V}{(e *(0.78 * p))} * 0.5
$$

Where $T$ is the residence (or flushing) time in days, $\mathrm{V}$ is the water volume of the tidal creek, 0.78 is a correction factor for the sinusoidal nature of tidal cycles, $e$ is exchange efficiency, and 0.5 accounts for the semi-diurnal tides. The exchange efficiency $(e)$ was estimated as 1 for $\mathrm{RC}$ and $\mathrm{MC}, 0.5$ for $\mathrm{BC} 3$ and 0.2 for $\mathrm{BC} 1$ based on creek geometry. All other values used in the calculations are given in Table 1. This model assumes no significant freshwater inflow into the tidal creeks, which is valid since the largest measured cumulative runoff during an exceptional flood was only $1 \%$ of peak tidal discharge at the mouth of the harbour (Williams et al. 2006).

\section{Statistical Analysis}

Statistical analysis was carried out using Statistica Version 6.0 (StatSoft). Differences in $\mathrm{P}_{\max }$ measured using $\mathrm{O}_{2}$ and ${ }^{13} \mathrm{C}$ measurements were compared using a t-test. A 2way analysis of variance (ANOVA) was carried out on log-transformed RC and MC wet and dry season data with site and season as factors. A 1-way ANOVA was carried out on long-transformed dry season data only from $\mathrm{RC}, \mathrm{MC}$ and $\mathrm{BC}$. The significance level (alpha) was specified as 0.05. A sequential Bonferroni (Sokal \& Rohlf 1995) was used to correct the alpha for multiple testing. In some cases, variances in the compared groups were heterogeneous (as indicated by Cochran's C-test). However, ANOVAs are robust to violations of the assumption of homogenous variances, provided that sample sizes are similar (Zar 1999), as was the case for most tests undertaken. The significance level was defined as 0.01 when Cochran's tests were 
violated to further reduce the chance of a type I error (falsely identifying a significant difference). Where significant differences were detected, post-hoc analysis was carried out using Tukey's HSD test. The assumption that the data points from the six sample sites share equal independence may be violated as there are two sampling locations within each creek (upstream and downstream). However, while downstream sites may be somewhat influenced by upstream sites, they are also strongly influenced by marine waters in the main body of the harbour due to the macrotidal regime. Therefore, for the purposes of this study it was assumed that all six sites share equal independence.

A multivariate ordination technique was used to examine the major source of variation in the process rate data. Principal component analysis (PCA) was carried out using benthic and pelagic processes as variables. The variables displayed strong collinearity due to the extreme values measured in $\mathrm{BC}$, therefore variables were either excluded in cases where multiple variables were measures of the same biogeochemical processes, or ratios were used. Variables included in the PCA, and the processes and co-variables they represent were: $\mathrm{P}_{\max }$ as a measure of pelagic metabolism (negatively correlated with respiration); $f$ DIC as a measure of benthic remineralization (positively correlated with $f \mathrm{NH}_{4}, f \mathrm{NO}_{x}, f \mathrm{PO}_{4}, f \mathrm{SiO}_{4}$, negatively correlated with $f \mathrm{DO}, f \mathrm{~N}_{2}$ ); denitrification efficiency (DE) as a measure of nitrogen release to the water column (negatively correlated with $f \mathrm{NH}_{4}$, positively correlated with $f \mathrm{~N}_{2}$ ); benthic primary production (bPP); $f \mathrm{DIC} / f \mathrm{PO}_{4}$ as a measure of phosphorus retention in the sediments; and $f \mathrm{DIC} / f \mathrm{O}_{2}$ as a measure of aerobic versus anaerobic organic matter degradation. 


\section{Results}

\section{Water Column Physico-Chemical Data}

Water quality in RC and MC were similar and varied seasonally (Table 2). Water temperature was relatively constant all year (approx. $30^{\circ} \mathrm{C}$ ). The surface waters were well saturated with oxygen (> $77 \%$ ) but varied with tides, being typically lower during low tide. During the dry season, MC and RC had high salinity (up to 37), very low nutrient concentrations $\left(<0.3 \mu \mathrm{M}\right.$ DIN and $\left.<0.21 \mu \mathrm{M} \mathrm{PO}_{4}{ }^{3-}\right)$ and very low $\mathrm{N}: \mathrm{P}$ ratios $(<1.5)$. During the wet season survey, freshwater from the Elizabeth River flowed into East Arm and was pushed into the tidal creeks during the flood tide, lowering the salinity (22-29) and increasing nitrogen concentrations (up to $1.9 \mu \mathrm{M}$ ). $\mathrm{N}: \mathrm{P}$ ratios increased during the wet season, particularly in $\mathrm{RC}$ (up to 12.5).

Concentrations of $\operatorname{chl} a$ in the water column remained relatively low all year round $\left(<3 \mu \mathrm{g}^{-1}\right)$. The euphotic depth decreased during the wet season and was also lower during low tide.

Sewage effluent strongly affected physico-chemical parameters in the water column. It was observed that sewage effluent entered the creek at $\mathrm{MC} 1$ from the mangroves following the tidal maximum and rapidly changed water quality conditions. Surface water during periods of sewage effluent discharge in MC had a higher temperature $\left(>32^{\circ} \mathrm{C}\right)$ and lower salinity ( 28) than the surrounding creek water (MC-S; Table 2), resulting in a temporary surface plume. Mean TSS and nutrient concentrations increased dramatically, chl $a$ concentrations were elevated $\left(9.9 \mu \mathrm{g} \mathrm{l}^{-1}\right)$ and the N:P ratio was higher than typical creek water (6.4). The sewage effluent plume caused a decrease in light penetration $\left(\mathrm{Z}_{\mathrm{eu}}=3 \mathrm{~m}\right)$ and oxygen saturation $(69 \%)$. As the tide receded, nutrient and TSS concentrations gradually decreased as the plume was 
dispersed and diluted. Within several hours the impact of the plume was undetected with nutrient concentrations and salinity returning to background levels.

Water quality in BC varied considerably over short sampling periods (4-5 hrs) in December 2008 as indicated by the high standard deviation values for most parameters (Table 2). Overall, during our sampling periods, salinity was lower and highly variable $(20.6 \pm 10.0)$ due to the influence of tides, terrestrial freshwater inputs and sewage effluent. Dissolved oxygen concentrations in BC were also much lower $(43 \pm 25 \%)$ than in the other two creeks and highly variable. Measured DO saturation ranged from less than $10 \%$ to supersaturation, with the lowest values occurring early in the mornings. The high phytoplankton biomass ( $\mathrm{chl} a$ ) and TSS concentrations limits light penetration, with the euphotic depth much lower $\left(Z_{\mathrm{eu}}=1.6\right)$. The mean nutrient concentrations in $\mathrm{BC}$ were several orders of magnitude higher than in the other two creeks, including the mean sewage effluent plume concentrations in MC (MC-S) (with the exception of $\mathrm{SiO}_{4}$ ) and nutrient concentrations in $\mathrm{BC}$ decreased downstream (data not shown).

Tidal flushing is restricted in $\mathrm{BC}$ by a sand bar across the mouth, a narrow channel and several large meander bends (Fig. 1c) and the estimated flushing time varied from 0.5 to $5 \mathrm{~d}$, depending on location in the creek and the nature of the tides (Table 1). The degree of flushing decreased upstream and during neap tides. In contrast, $\mathrm{RC}$ and MC have wide open mouths and relatively straight channels (Fig. 1a \& b), allowing efficient flushing. Hence, estimated flushing times were shorter $(\sim 0.5 \mathrm{~d}$; Table 1$)$ and both creeks were well flushed with water from East Arm during each tidal cycle. This is consistent with the observed sewage effluent plume in MC1 which was diluted and dispersed following each low tide. 


\section{Sediment Characteristics}

Sediment TOC, TN and TP concentrations were higher at the upstream sites reflecting the higher mud content (as indicated by porosity). Mean TOC concentrations ranged from 1.8 to $4.6 \mathrm{wt} \%$ and were highest at $\mathrm{RC} 1$ and $\mathrm{BC} 1$. TN concentrations ranged from 0.08 to $0.42 \%$ and were highest in $\mathrm{BC}$. TP concentrations were highest in $\mathrm{BC}$ (997 to $1363 \mathrm{mg} \mathrm{kg}^{-1}$ ) and MC1 (762-825 $\left.\mathrm{mg} \mathrm{kg}^{-1}\right)$ compared to the other sites $(<646$ $\mathrm{mg} \mathrm{kg}^{-1}$ ). The molar $\mathrm{C}: \mathrm{P}$ ratios in $\mathrm{BC}$ and $\mathrm{MC}$ were lower than typical terrestrial and marine $\mathrm{C}: \mathrm{P}$ ratios $(\mathrm{C}: \mathrm{P}<106)$ suggesting an additional phosphorus source, most likely from sewage. The mean $\delta^{13} \mathrm{C}$ values ranged between -25.7 and $-23.3 \%$ and the mean $\delta^{15} \mathrm{~N}$ values ranged from 2.3 to $12.6 \%$ with the most enriched values in BC and at MC1 (Table 3). Benthic chl $a$ concentrations ranged from 17 to $60 \mathrm{mg} \mathrm{m}^{-2}$ in $\mathrm{RC}$ and $\mathrm{MC}$ and were higher in $\mathrm{BC}$, ranging from 161 to $532 \mathrm{mg} \mathrm{m}^{-2}$ (Table 3).

\section{Pelagic Primary Production and Respiration}

$\mathrm{P}_{\max }$ rates measured as both $\mathrm{O}_{2}$ and ${ }^{13} \mathrm{C}$ gave comparable results (data not shown) with no significant differences between the two methods ( $\mathrm{p}=0.977$, $\mathrm{t}$-test). The ${ }^{13} \mathrm{C}$ results are reported herein since this method was used to calculate depth-integrated production. $\mathrm{P}_{\max }$ rates in $\mathrm{BC}$ were significantly higher (1-way ANOVA, $\mathrm{p}<0.02532$, Fig. 2) than in the other two creeks with values ranging from 23.5 to $42.7 \mathrm{mmol} \mathrm{C} \mathrm{m}^{-3}$ $\mathrm{h}^{-1}$ and these two sites were significantly different from each other. Mean $\mathrm{P}_{\max }$ rates in $\mathrm{MC}$ and RC were similar, ranging from 1.17 to $2.93 \mathrm{mmol} \mathrm{C} \mathrm{m}^{-3} \mathrm{~h}^{-1}$ and there were no significant differences between sites or season, however there were significant interactions between site and season (2-way ANOVA, p<0.05, Table 4). Mean respiration rates in $\mathrm{BC}$ ranged from 4.5 to $10.8 \mathrm{mmol} \mathrm{O}_{2} \mathrm{~m}^{-3} \mathrm{~h}^{-1}$ and were significantly higher at BC1 (1-way ANOVA, p<0.02532, Fig. 2) compared to other 
sites. In RC and MC, respiration rates were similar and low, ranging from 0.73 to 1.82 mmol O $\mathrm{O}^{-3} \mathrm{~h}^{-1}$ with no significant differences in season or site (Table 4). The sewage effluent plume in MC was sampled on one occasion during the October 2007 survey (MC-S) and $\mathrm{P}_{\max }$ (measured using the $\mathrm{O}_{2}$ syringe method) and respiration rates (19.1 and $8.6 \mathrm{mmol} \mathrm{O}_{2} \mathrm{~m}^{-3} \mathrm{~h}^{-1}$, respectively) were significantly higher than other sites in $\mathrm{RC}$ and $\mathrm{MC}$ but comparable to $\mathrm{BC} 1$ and $\mathrm{BC} 3$.

Mean depth-integrated primary production (NPP) ranged from 10.1 to $248.5 \mathrm{mmol} \mathrm{C}$ $\mathrm{m}^{-2} \mathrm{~d}^{-1}$ and there were significant differences between the 6 sites (1-way ANOVA, $\mathrm{p}<0.01$, Fig. 3). Net primary production rates were similar at RC1, RC2 and MC3, ranging between 10.1 and $16.5 \mathrm{mmol} \mathrm{C} \mathrm{m}^{-2} \mathrm{~d}^{-1}$. Net primary production at MC1 was significantly higher $\left(40.8 \mathrm{mmol} \mathrm{C} \mathrm{m} \mathrm{m}^{-2}\right)$ than at other sites in $\mathrm{MC}$ and $\mathrm{RC}$, and in $\mathrm{BC}$, net primary production was significantly higher than all sites in $\mathrm{MC}$ and $\mathrm{RC}$, ranging from 130.9 to $248.5 \mathrm{mmol} \mathrm{C} \mathrm{m} \mathrm{d}^{-1}$.

Mean community respiration ranged from 50.4 to $519 \mathrm{mmol} \mathrm{C} \mathrm{m} \mathrm{d}^{-1}$ (Fig. 3). Mean community respiration rates were significantly higher at $\mathrm{BC} 1$, and $\mathrm{MC} 1$ and $\mathrm{BC} 3$ were also significantly higher than other sites in MC and RC (1-way ANOVA, $\mathrm{p}<0.02532$ ). Respiration exceeded production at all sites and the GPP:CR ratio was $\leq 1$ at all sites with the lowest values (0.5-0.7) at sites in MC and RC, and higher values in $\mathrm{BC}(0.9-1.0)$.

\section{Benthic Respiration and Production}

Mean dark DIC fluxes ranged from 58.8 to $390.8 \mathrm{mmol} \mathrm{C} \mathrm{m}^{-2} \mathrm{~d}^{-1}$ and were significantly higher in BC (1-way ANOVA, p<0.01, Fig. 2). Mean dark DO fluxes varied from -40.0 to $-90.5 \mathrm{mmol} \mathrm{m}^{-2} \mathrm{~d}^{-1}$ and there were no significant differences 
between the six sites. There were no significant differences in DO or DIC fluxes between sites or seasons in MC and RC (Table 4).

There was diurnal variation in DIC and DO fluxes, with reduced DIC efflux and DO influx measured in all light chambers. However, the semi-diurnal, macrotidal regime generates constant variations in light conditions at the sediment surface. Light conditions varied both within and between sites and were not reproducible between sites or sampling periods. Therefore, it was not possible to calculate light fluxes on a mmol m $\mathrm{m}^{-2} \mathrm{~d}^{-1}$ basis. The reduced DIC and increased $\mathrm{O}_{2}$ fluxes measured in the light chambers suggest the presence of microbenthic algae (MBA) at all sites. This was confirmed by measurable benthic primary productivity rates, indicating uptake of DIC by MBA, with the exception of RC1 where primary productivity rates were below detection limits. However, sediment chl $a$ concentrations at this site were similar to other sites in RC and MC (Table 3). Sediment primary production rates were all low and similar in all three tidal creeks $\left(<8 \mathrm{mmol} \mathrm{C} \mathrm{m}^{-2} \mathrm{~d}^{-1}\right.$, Fig. 3), despite higher benthic algal biomass in $\mathrm{BC}$. The $\mathrm{P}: \mathrm{R}$ ratio of the sediments was very low at all sites $(<0.25)$.

\section{Dissolved nutrient fluxes}

Benthic nutrient fluxes were very high in $\mathrm{BC}$ compared to the other two creeks where similar fluxes were measured (Fig. 2). At all sites, the sediments were a source of inorganic nutrients for the overlying water with a net efflux of DIN, $\mathrm{PO}_{4}$ and $\mathrm{SiO}_{4}$. There were no significant differences in nutrient fluxes between seasons in RC and $\mathrm{MC}$, except for $\mathrm{SiO}_{4}$ fluxes which were significantly higher in the dry season (2-way ANOVA, p<0.05, Table 4). 
In $\mathrm{RC}$ and $\mathrm{MC}$, mean dark $\mathrm{NH}_{4}{ }^{+}$fluxes ranged from 0.32 to $1.12 \mathrm{mmol} \mathrm{N} \mathrm{m} \mathrm{d}^{-2}$, accounting for $>65 \%$ of the DIN flux. There were no significant differences between seasons or sites (Table 4). In BC, mean dark $\mathrm{NH}_{4}{ }^{+}$fluxes were significantly higher (1way ANOVA, p<0.02532, Fig. 2), ranging from 21.9 to $45.0 \mathrm{mmol} \mathrm{N} \mathrm{m}^{-2} \mathrm{~d}^{-1}$, accounting for $>94 \%$ of the DIN flux in this creek. $\mathrm{NO}_{\mathrm{x}}$ fluxes were highly variable with the standard deviation at each site typically exceeding the mean fluxes. $\mathrm{NO}_{\mathrm{x}}$ fluxes were significantly higher at MC1 compared to other sites in MC and RC (2way ANOVA, $\mathrm{p}<0.01$, Table 4). However, when comparing all six sites, there was no significant difference in $\mathrm{NO}_{\mathrm{x}}$ fluxes (Fig. 2). Mean $\mathrm{PO}_{4}{ }^{3-}$ fluxes in $\mathrm{RC}$ and $\mathrm{MC}$ ranged from 0.06 to $0.21 \mathrm{mmol} \mathrm{P} \mathrm{m}^{-2} \mathrm{~d}^{-1}$ and there were no significant differences in sites or seasons. A significant interaction was found between season and site (2-way ANOVA, $\mathrm{p}<0.05$, Table 4), however the post hoc comparison (Tukey's HSD test) failed to identify where these interactions occurred. $\mathrm{PO}_{4}{ }^{3-}$ fluxes were significantly higher in BC compared to sites in RC and MC (1-way ANOVA, p<0.02532, Fig. 2), ranging from 1.50 to $15.2 \mathrm{mmol} \mathrm{P} \mathrm{m}^{-2} \mathrm{~d}^{-1}$, and these two sites were also significantly different from each other. Mean $\mathrm{SiO}_{4}$ fluxes ranged from 3.26 to $45.4 \mathrm{mmol} \mathrm{Si} \mathrm{m}{ }^{-2} \mathrm{~d}^{-1}$ and the flux at BC1 was significantly higher than at the other sites ( $p<0.05$, ANOVA).

\section{Denitrification (net N2 fluxes)}

Measured $\mathrm{N}_{2}$ fluxes in $\mathrm{RC}$ and $\mathrm{MC}$ were consistently high ranging from 5.50 to 6.83 mmol N m $\mathrm{d}^{-1}$ (Fig. 2). Variability was sometimes high among replicate chambers, but in all cases $\mathrm{N}_{2}$ fluxes were greater than the DIN fluxes. No data was collected from RC1.

There were difficulties calculating $\mathrm{N}_{2}$ fluxes in $\mathrm{BC}$ due to missing data and highly variable rates in replicate chambers, with both positive and negative fluxes calculated. 
However, overall mean $\mathrm{N}_{2}$ fluxes in $\mathrm{BC}$ were lower than the $\mathrm{N}_{2}$ fluxes in the other two tidal creeks and fluxes at BC1 were significantly lower (p<0.02532, Fig. 2).

Denitrification removed a major portion of the $\mathrm{N}$ cycled through the sediments in $\mathrm{RC}$ and MC. The mean denitrification efficiency ranged from 83 to $97 \%$ at sites in $\mathrm{RC}$ and MC. In contrast, the majority of $\mathrm{N}$ flux to the water column in $\mathrm{BC}$ was in the form of $\mathrm{NH}_{4}{ }^{+}$and denitrification only removed a small proportion $(\mathrm{DE}<10 \%)$ of the $\mathrm{N}$ cycled through the sediments.

\section{Principal Components Analysis}

The first two PCA axes cumulatively explained $94.4 \%$ of the total variation in biogeochemical data and the discussion will be limited to these main axes. PCA axis 1 , which alone accounted for $81.4 \%$ of the variation, was highly correlated with variables related to benthic remineralization $(f \mathrm{DIC})$ and pelagic metabolism $\left(\mathrm{P}_{\max }\right)$. Denitrification efficiency (DE), the degree of anaerobic respiration $\left(f \mathrm{DIC} / f \mathrm{O}_{2}\right)$ and phosphorus retention $\left(f \mathrm{DIC} / f \mathrm{PO}_{4}\right)$ were strongly negative on this axis (Fig. 4a). PCA axis 2 , which accounted for only $13.0 \%$ of the variation, was determined by benthic primary production (bPP) and phosphorus retention $\left(f \mathrm{DIC} / f \mathrm{PO}_{4}\right)$ to a lesser degree.

Sites in BC had high positive scores on axis 1 and there was a downstream gradient with higher scores at $\mathrm{BC} 1$ than $\mathrm{BC} 3$ (Fig. 4b). All sites in $\mathrm{MC}$ and $\mathrm{RC}$ had similar scores on axis 1 and were all slightly negative, except for MC1 in the dry season which was close to zero on this axis. Sites in MC and RC were spread across axis 2 with no obvious trends between sites or seasons. The 3 sites with strongly negative scores on this axis all had the highest benthic primary productivity values. Sites with negative axis 1 scores and positive axis 2 scores typically had very low benthic 
primary productivity rates and high $f \mathrm{DIC} / f \mathrm{PO}_{4}$ ratios indicating strong phosphorus retention in the sediments.

The position of the sites in the ordination space indicates the main similarities and differences in biogeochemical variables between sites. Sites in BC were most different from sites in the other two creeks, and were also different from each other. This is consistent with the significant differences observed in benthic and pelagic processes between sites in BC and the other two creeks (Fig. 2 and Fig. 3). Although there were differences between sites in $\mathrm{MC}$ and $\mathrm{RC}$ along axis 2, this axis only explains a small proportion (13.0\%) of the variance and is therefore less important that the differences observed along axis 1 .

\section{Discussion}

\section{Effect of nutrient loads on biogeochemical processes}

Our results, which integrate multiple biogeochemical processes in three tropical tidal creeks, indicate a substantial impact of sewage effluent on rates of benthic and water column nutrient cycling in the hypereutrophic creek (BC), but effects on benthic processes only in the oligotrophic-mesotrophic creek (MC) relative to the reference site (RC). There was a downstream gradient in the creeks receiving sewage effluent, with the greatest effects measured at $\mathrm{BC} 1$ and $\mathrm{MC} 1$, closest to the sewage discharge points.

The most affected processes in BC were benthic nutrient fluxes ( $f \mathrm{DIN}, f \mathrm{DIP}$ ), denitrification $\left(f \mathrm{~N}_{2}\right)$ and primary production $\left(\mathrm{P}_{\max }\right)$ which were one to two orders of magnitude higher or lower than in RC (Fig. $5 c \& d$ ). The combination of increased DIN flux and decreased $\mathrm{N}_{2}$ flux subsequently affected the denitrification efficiency 
which was up to three orders of magnitude lower in BC relative to RC (Fig. 5d). Denitrification provides a sink in the nitrogen budget and thereby plays an important role in controlling the degree of eutrophication in waters subjected to substantial anthropogenic input of nutrients (Seitzinger 1988; Rysgaard et al. 1995). The low denitrification efficiency in BC is consistent with studies in other estuarine systems which have demonstrated that as nutrient loads increase, denitrification removes a smaller proportion of the load (Sloth et al. 1995; Burford \& Longmore 2001; Caffrey et al. 2007). The effect of nutrient loading on denitrification efficiency has important implications for the nutrient status of the system and has flow-on effects that alter the structure of higher trophic levels such as fish and invertebrate communities (Kemp et al. 2005).

Dissolved inorganic nutrient concentrations (DIN and $\left.\mathrm{PO}_{4}\right)$ and phytoplankton biomass ( $\mathrm{chl} a$ ) were one to two orders of magnitude greater in $\mathrm{BC}$ than in RC (Fig. 5a). Depth-integrated primary production and respiration, sediment algal biomass and benthic respiration were also higher in $\mathrm{BC}$ but to a lesser degree (Fig. 5). The presence of a high phytoplankton biomass in BC limited light penetration, with the euphotic depth several times lower than in the other two creeks. Additionally, the high phytoplankton biomass, combined with high pelagic respiration rates, resulted in substantial diel fluctuations in $\mathrm{O}_{2}$ concentrations. High benthic respiration rates in $\mathrm{BC}$ also emphasize the potential importance of this pathway to contribute to $\mathrm{O}_{2}$ depletion (Boynton \& Kemp 1985). The low DO saturation in the early mornings indicates high rates of night-time respiration and suggests $\mathrm{BC}$ experiences regular hypoxia. Overall, DO saturation in $\mathrm{BC}$ was approximately half that found in RC (Fig. 5a). BC has experienced periodic fish kills along the entire length of the creek and it is likely a lack of oxygen is responsible. 
In contrast, there was a relatively minor effect of increased, but smaller nutrient loads in $\mathrm{MC}$ relative to $\mathrm{RC}$ and importantly, the impacts were observed only in the water column at MC1, which is adjacent to the sewage discharge point. All variables at site MC3 were similar to sites in RC. Dissolved inorganic nutrient concentrations were most affected at MC1 and were approximately one order of magnitude greater than RC (Fig. 5a). Pelagic primary production, respiration and phytoplankton biomass were also affected to a lesser degree (Fig. $5 \mathrm{a} \& \mathrm{~b}$ ). There were minor differences in sediment quality and benthic processes at MC1 with sediment chl $a$ and TP concentrations, $\delta^{15} \mathrm{~N}$ and DIP fluxes slightly higher compared to other sites in MC and RC. As such, small scale nutrient inputs appear to have a greater impact on pelagic rather than benthic processes and parameters, but at larger scale nutrient inputs, benthic processes are most affected (Fig. 5). This pattern is most likely due to differences in both the magnitude of effluent inputs and the hydrodynamics in the two creeks (see below).

Biogeochemical process rates measured in $\mathrm{BC}$ far exceeded any previously reported values for Darwin Harbour and other tropical estuaries (Table 5). Based on our study, $\mathrm{BC}$ is considered to be hypereutrophic (Nixon 1995). Pelagic metabolism and benthic nutrient fluxes in $\mathrm{BC}$ were similar to that found in other tropical hypereutrophic systems such as shrimp ponds (e.g. Alongi et al. 1999a; Burford \& Longmore 2001). The high benthic nutrient fluxes and low denitrification efficiency in $\mathrm{BC}$ indicate the sediments were a major source of dissolved inorganic nutrients to the water column and, combined with the sewage effluent, contribute to increased algal biomass and poor water quality. The similarity between benthic primary productivity in all creeks, despite the higher benthic algal biomass in BC, suggests high TSS and phytoplankton biomass decreased light availability at the sediment surface. Additionally, in BC the 
dense algal mat, as demonstrated by the high chl $a$ concentrations, is likely to cause self-shading.

In MC, the impact of increased nutrient loads was restricted to the water column adjacent to the sewage discharge point, consistent with a locally mesotrophic system (Nixon 1995). The treated sewage effluent had a high proportion of ammonium, nitrate and phosphate relative to the typical creek water but lower relative concentrations of phytoplankton which is consistent with other studies (e.g. Jones et al. 2001). Therefore, while there may not be direct input of phytoplankton biomass with the sewage effluent, the additional nutrients stimulated in situ primary production in the creek water. The elevated TP concentrations and $\delta^{15} \mathrm{~N}$ signature of sediments at MC1 suggest sewage-derived material is deposited at this site, however, there was no increase in benthic metabolism and nutrient fluxes at this site, indicating the sewage-derived nutrients and associated primary production were not being recycled through the sediments in MC.

Depth-integrated pelagic primary production rates in $\mathrm{RC}$ and $\mathrm{MC}$ were lower than values reported for the shallow margins of Darwin Harbour (Burford et al. 2008) as well as tropical coastal waters in Australia and around the world (Table 5). These tidal creeks are considered to be oligotrophic and are net heterotrophic (P:R ratios in the water column were $\leq 1$ ). This is in contrast to the main body of the harbour which is autotrophic (Burford et al. 2008). The higher turbidity in the tidal creeks results in a shallower euphotic zone and therefore pelagic primary production is likely to be light limited relative to the main body of the harbour (McKinnon et al. 2006). The rates of benthic remineralization in $\mathrm{RC}$ and $\mathrm{MC}$ were similar to rates reported for other tropical mangrove environments including Darwin Harbour (Table 5). Denitrification 
rates in these creeks were high but comparable to the range of estimates for other estuarine and coastal marine sediments (Seitzinger 1988).

In comparison to the sewage-derived nutrient inputs, the seasonal input of nutrients associated with freshwater runoff during the wet season has no effect on biogeochemical processes in the tidal creeks. This is in accordance with the limited seasonal change in key parameters such as temperature and organic matter supply from mangroves. The seasonal variations in water column nutrient concentrations in $\mathrm{MC}$ and $\mathrm{RC}$ were minor compared to variations observed at sites affected by sewage effluent.

\section{Controls on Biogeochemical Processes}

Pelagic primary production was strongly associated with benthic remineralization in the PCA, suggesting benthic-pelagic coupling. The higher pelagic primary production, a $\mathrm{P}: \mathrm{R}$ ratio close to 1 and low $\mathrm{C}: \mathrm{N}$ and $\mathrm{C}: \mathrm{P}$ ratios in $\mathrm{BC}$ all reflect a significant algal contribution and suggest phytoplankton detritus was an important source of organic matter to the sediments in this creek. Therefore, the increased benthic remineralization in $\mathrm{BC}$ was a response to the stimulated primary production in the water column. Additionally, primary production in the water column was stimulated by benthic nutrient fluxes. Benthic nutrient regeneration in $\mathrm{BC}$ was far greater than phytoplankton demand for net growth, which was limited by light availability below the surface. This results in the accumulation of DIN and $\mathrm{PO}_{4}{ }^{3-}$ in the water column. Overall, there was strong coupling between benthic and pelagic processes in $\mathrm{BC}$.

In RC and MC, depth-integrated primary production rates were much lower than the benthic remineralization rates, indicating phytoplankton production contributes only a 
small proportion of the overall organic matter pool in the sediment surface. Sediment organic matter was driving benthic metabolism rather than phytoplankton detritus in these two tidal creeks. In addition, benthic regenerated nutrients were not sufficient to supply all the nutrients required for phytoplankton growth in these creeks. The remaining nutrient requirements by phytoplankton are likely supplied by oceanic or terrestrial inputs (Burford et al. 2008; Ferrón et al. 2009). The high denitrification rates in $\mathrm{RC}$ and $\mathrm{MC}$ indicate this is the main process controlling nitrogen release to the water column in the tidal creeks and support the suggestion that nitrogen is limiting phytoplankton growth in Darwin Harbour (Burford et al. 2008). $\mathrm{NO}_{3}{ }^{-}$levels in the water column were low and only infrequently was there $\mathrm{NO}_{3}{ }^{-}$influx, indicating denitrification was controlled by coupled nitrification-denitrification, as is commonly found in coastal marine systems (Seitzinger 1988).

Denitrification efficiency and phosphorus retention were strongly associated with the degree of anaerobic degradation in the PCA, suggesting sediment oxygen consumption was important in controlling nitrogen and phosphorus release. In the tidal creeks, the community respiratory quotient $\left(\mathrm{CRQ}=\mathrm{DIC} / \mathrm{O}_{2}\right)$ was -2 in the oligotrophic creeks and -4 in the hypereutrophic creek, indicating a shift to dominance of anaerobic mineralization processes with the increased nutrient loading in BC. This shift from aerobic to anaerobic metabolism occurs during hypoxic events, caused by excess nutrient inputs, and involves profound changes in the biogeochemical cycles of phosphorus and nitrogen (Conley et al. 2009; Soetaert \& Middelburg 2009).

One of the most prominent effects of hypoxia is the increased P flux from sediments (Conley et al. 2009). Phosphate fluxes are controlled by release from degradation of organic matter and by the buffering mechanism involving iron oxides at the sediment 
surface (Froelich 1988). The low oxygen conditions and dominance of anaerobic metabolism pathways in $\mathrm{BC}$ contributed to the large benthic $\mathrm{PO}_{4}{ }^{3-}$ flux. The ratio of DIC to $\mathrm{PO}_{4}{ }^{3-}$ fluxes was low in $\mathrm{BC}$ indicating little or no phosphorus retention in the sediment. Under small or no increased nutrient loads in MC and RC, the ratio of DIC to $\mathrm{PO}_{4}{ }^{3-}$ fluxes was high, indicating strong phosphate retention by the sediments. The low efflux of remineralized phosphate is likely controlled in the surface oxidized layer by sorption with iron oxyhydroxides (Patrick \& Khalid 1974).

Hypoxia also affects nitrogen release to the water column which is strongly controlled by denitrification. Denitrification appears to be inhibited in $\mathrm{BC}$ and there are several possible mechanisms. It is likely the low oxygen conditions cause a breakdown in the nitrification-denitrification coupling by inhibiting nitrification. Nowicki (1994) found that highly reduced conditions in enriched sediments near sewage outfalls restricted $\mathrm{O}_{2}$ penetration and limited nitrification. Additionally, sulfate reduction, the predominant pathway of anaerobic metabolism, produces sulfide which inhibits nitrification (Seitzinger 1988). Therefore, in BC where anaerobic metabolism dominates, denitrification rates could be indirectly affected by sulfide if nitrification is suppressed. This is supported by the large proportion of $\mathrm{N}$ present as $\mathrm{NH}_{4}{ }^{+}$.

Processes affected by hypoxia, such as denitrification and phosphorus retention, display threshold-like behavior (Webster \& Harris 2004; Conley et al. 2009; Eyre \& Ferguson 2009). Regime shifts, involving an abrupt change in ecosystem processes, can occur once specific thresholds of nutrient inputs are exceeded and this can cause changes in biological variables that propagate through several trophic levels (Conley et al. 2009). The breakdown of coupled nitrification-denitrification and subsequent low denitrification efficiency, as well as the large flux of $\mathrm{PO}_{4}{ }^{3-}$ from the sediments to 
the water column, suggests that thresholds have been exceeded in BC. This is

consistent with the theory that an ecosystem has reached a threshold when the system switches to one dominated by anaerobic processes (Conley et al. 2009) as was found in BC. The nutrient loads entering MC are sufficiently small to have not impacted these key biogeochemical processes, with $\mathrm{PO}_{4}{ }^{3-}$ fluxes and denitrification efficiencies similar to those observed in the comparatively pristine tidal creek. While there is some evidence of sewage-derived material being deposited at $\mathrm{MC} 1$, the assimilation capacity of the sediments has not yet been exceeded.

The processes occurring in $\mathrm{BC}$ follow the generally accepted conceptual models of eutrophication (e.g. Nixon 1995; Cloern 2001) whereby an increase in the input of nutrients (in this case from sewage effluent) has stimulated primary production in the water column, leading to enhanced sedimentation of algal-derived organic matter, stimulation of microbial decomposition and oxygen consumption and depletion of water column oxygen. There has been a shift in dominance from aerobic to anaerobic metabolism and as a result, coupled nitrification-denitrification is inhibited and oxidebound phosphorus released. Thus more nutrients are recycled back into the water column, further stimulating primary production (Kemp et al. 1990; Eyre \& Ferguson 2002). Nutrient-generated increases in algal biomass fuel respiration and lead to light limitation of the phytoplankton and benthos, further generating hypoxic conditions. Ultimately, there is a positive feedback accelerating eutrophication through internal loading of nutrients (McGlathery et al. 2004).

\section{Influence of physical processes}

The effluent loads are similar between $\mathrm{BC}$ and $\mathrm{MC}$ but the response of many biogeochemical processes was far greater in BC (Fig. 5). This suggests that nutrient 
load alone was not responsible for the observed effects on biogeochemical processes in $\mathrm{BC}$, and there must be consideration of additional processes or factors. The susceptibility of estuaries to eutrophication varies and it is now well recognized that physical attributes, including tidal mixing and associated residence times and optical properties, act as a filter to modulate the response to nutrient loading (Cloern 2001).

The estimated residence times in the three tidal creeks vary both spatially and temporally and are controlled by the tidal regime and geomorphology (Wolanski et al. 1992; Wolanski et al. 2000). The lower reaches of the tidal creeks are flushed efficiently by tidal action while significant trapping can occur in the upper reaches of $\mathrm{BC}$, particularly during neap tides when tidal flushing is limited. This is typical of tropical mangrove-lined tidal creeks, for example, Wolanski et al. (2000) reported that water may reside in the upper reaches of tidal creeks for between 5-15 days, and flushing is rapid near the mouth. Longer residence times reduce export of nutrients (Nixon et al. 1996) and favour local degradation of phytoplankton detritus (Koné \& Borges 2008), leading to low dissolved oxygen concentrations and nutrient enrichment (Boto \& Bunt 1981; Trott \& Alongi 1999) and enable benthic processes to have a greater impact on the system. Therefore, the impact on biogeochemical processes from excess nutrients is most severe in systems where tidal flushing is limited (Jickells 1998; Herbert 1999), as is the case in BC, and physical processes play a key role in reducing the risk of algal blooms, hypoxic events and subsequent changes in dominant biogeochemical processes in the tidal creeks.

Other physical processes may also influence biogeochemical processes, particularly sediment resuspension (Ståhlberg et al. 2006). Potential effects of resuspension include increased benthic mineralization, a decline in pelagic $\mathrm{O}_{2}$ concentration, 
release of porewater nutrients to the water column, desorption of compounds from suspended sediment particles, decreased light availability and physical disturbance leading to a decrease of benthic primary production (Hopkinson 1985; Sloth et al. 1996; Wainright \& Hopkinson 1997; Ståhlberg et al. 2006; Almroth et al. 2009). In the shallow tidal creeks of Darwin Harbour, more or less continuous resuspension caused by the semi-diurnal tides can be found, resulting in a system which is in a constant state of flux. It is therefore likely that the biogeochemical process rates reflect the mean environmental conditions in a continuously changing system.

\section{Implications for tropical estuaries}

Ecosystem alteration due to anthropogenic nutrient loading of coastal zones is occurring at a rapid rate in the tropics (Downing et al. 1999). The impact on the ecological functioning of coastal ecosystems varies in intensity and spatial distribution, both locally and globally. This study found that the effect of increased nutrient loads on biogeochemical processes can vary over small spatial scales (i.e. individual tidal creeks), and this is confounded by physical processes, principally residence time. These findings are relevant over larger spatial scales. For example, the importance of denitrification can be assessed on an estuary-wide scale. A whole-ofharbour nitrogen budget for Darwin Harbour found a net import of $\mathrm{N}$ to the harbour from the ocean of approximately 15,000 $\mathrm{t} \mathrm{N} \mathrm{yr}^{-1}$ (Burford et al. 2008), however, denitrification was not included in this budget but it was suggested it may be an important process. Although the dataset from this study is limited, our calculations confirm that there could be an approximate equivalent export of $\mathrm{N}$ from Darwin Harbour as a result of denitrification. Therefore, denitrification represents an important process controlling the amount of $\mathrm{N}$ in the harbour as a whole. This is 
consistent with what has been found throughout the tropics, where microbial denitrification removes biologically available forms of nitrogen from the water column producing substantial deficits relative to other nutrients (Beman et al. 2005). A decrease in denitrification efficiency, as has been observed in $\mathrm{BC}$, can increase the availability of $\mathrm{N}$ in the water column and stimulate primary production which has important implications on the health and functioning of the whole ecosystem. Further research is needed to determine the actual contribution of denitrification to the nitrogen budget for Darwin Harbour.

Overall, the impacts of increased nutrient loads from sewage effluent are relatively localized and Darwin Harbour, as with most estuaries in tropical northern Australia, is considered to be relatively pristine. Forecasted increases in population and urbanization of Darwin will increase the nitrogen and phosphorus loads entering the harbour as catchment runoff and STP discharge increase. This will pose mounting pressure on estuarine health on a larger scale. This study has provided measurements of key biogeochemical processes in Darwin Harbour to inform predictive models used by estuarine managers. Additionally, the study of biogeochemical processes in disturbed and relatively pristine tidal creek systems provides important information which will enable comparison with other, more adversely affected tropical estuaries, such as those in southeast Asia.

\section{Conclusions}

This study has provided a comparison of rates of multiple biogeochemical processes across three scales of sewage nutrient loading in tropical tidal creeks to identify which processes are most sensitive to increased loading, thereby providing a broad perspective of the links between nutrient loads and biogeochemical processes. We 
have shown that both benthic and pelagic biogeochemical processes are significantly affected by increased nutrient loads, particularly under the combined influence of poor tidal flushing. Denitrification, benthic nutrient fluxes and pelagic primary production were identified as the biogeochemical processes most affected by nutrient loading in these tidal creek systems. High levels of oxygen consumption, caused by stimulated primary production and respiration, lead to intermittent hypoxia. This causes an alteration in the key processes controlling nutrient release, resulting in hypereutrophic conditions. The integrated approach used in this study provides relevant information for other tropical estuaries subject to anthropogenic nutrient loading around the world.

\section{Acknowledgements}

We wish to thank the staff from the Aquatic Health Unit at the Northern Territory Department of Natural Resources, Environment, The Arts and Sport for assistance with boats and logistics, Emily Saeck, Dominic Valdez, Matt Carey and Craig Smith for assistance with field work and laboratory analysis, Janice Trafford (GA) for MIMS analysis, Ed Czobik (NSW DECC) and Frank Krikowa (UC) for nutrient analysis, Liz Webber (GA) for XRF analysis, Rene Diocares (GU) and Rebecca Esmay (CMAR) for isotope analysis, Lesley Clemenston (CMAR) for chlorophyll analysis and Eric Valentine (CDU) for relevant information. We thank Rhys Leeming (CMAR), Alix Post (GA) and 2 anonymous reviewers whose useful comments substantially improved earlier versions of this manuscript.

This project was conducted as part of the Tropical Rivers and Coastal Knowledge (TRaCK) program. TRaCK receives major funding for its research through the Australian Government's Commonwealth Environment Research Facilities initiative; the Australian Government's Raising National Water Standards Program; Land and Water Australia; the Fisheries Research and Development Corporation and the Queensland Government's Smart State Innovation Fund.

This publication has received permission from the CEO of Geoscience Australia.

\section{References}

Almroth E, Tengberg A, Andersson JH, Pakhomova S, Hall POJ (2009) Effects of resuspension on benthic fluxes of oxygen, nutrients, dissolved inorganic 
carbon, iron and manganese in the Gulf of Finland, Baltic Sea. Continental Shelf Res 29: 807-818

Alongi DM, Dixon P, Johnston DJ, Van Tien D, Thanh Xuan T (1999a) Pelagic processes in extensive shrimp ponds of the Mekong delta, Vietnam. Aquaculture 175: 121-141

Alongi DM, Sasekumar A, Chong VC, Pfitzner J, Trott LA, Tirendi F, Dixon P, Brunskill GJ (2004) Sediment accumulation and organic material flux in a managed mangrove ecosystem: estimates of land-ocean-atmosphere exchange in peninsular Malaysia. Mar Geol 208: 383-402

Alongi DM, Tirendi F, Dixon P, Trott LA, Brunskill GJ (1999b) Mineralization of Organic Matter in Intertidal Sediments of a Tropical Semi-enclosed Delta. Estuar Coast Shelf Sci 48: 451-467

Alongi DM, Wattayakorn G, Pfitzner J, Tirendi F, Zagorskis I, Brunskill GJ, Davidson A, Clough BF (2001) Organic carbon accumulation and metabolic pathways in sediments of mangrove forests in southern Thailand. Mar Geol 179: $85-103$

Beman JM, Arrigo KR, Matson PA (2005) Agricultural runoff fuels large phytoplankton blooms in vulnerable areas of the ocean. Nature 434: 211-214

Bianchi TS (2007) Biogeochemistry of Estuaries. Oxford University Press, New York

Boto KG, Bunt JS (1981) Dissolved oxygen and pH relationships in northern Australian mangrove waterways Limnol Oceanogr 26: 1176-1178 
Bouillon S, Connolly RM (2009) Carbon Exchange Among Tropical Coastal Ecosystems. In: Nagelkerken I (Ed) Ecological Connectivity among Tropical Coastal Ecosystems (pp 45-70). Springer, Dordrecht

Boynton W, Hagy J, Cornwell J, Kemp W, Greene S, Owens M, Baker J, Larsen R (2008) Nutrient Budgets and Management Actions in the Patuxent River Estuary, Maryland. Estuaries and Coasts 31: 623-651

Boynton WR, Kemp WM (1985) Nutrient regeneration and oxygen consumption by sediments along an estuarine salinity gradient. Mar Ecol Prog Ser 23: 45-55

Burford MA, Alongi DM, McKinnon AD, Trott LA (2008) Primary production and nutrients in a tropical macrotidal estuary, Darwin Harbour, Australia. Estuar Coast Shelf Sci 79: 440-448

Burford MA, Longmore AR (2001) High ammonium production from sediments in hypereutrophic shrimp ponds. Mar Ecol Prog Ser 224: 187-195

Caffrey J, Murrell M, Wigand C, McKinney R (2007) Effect of nutrient loading on biogeochemical and microbial processes in a New England salt marsh. Biogeochemistry 82: 251-264

Clarke AL, Weckström K, Conley DJ, Anderson NJ, Adser F, Andrén E, de Jonge VN, Ellegaard M, Juggins S, Kauppila P, Korhola A, Reuss N, Telford RJ, Vaalgamaa S (2006) Long-term trends in eutrophication and nutrients in the coastal zone. Limnol Oceanogr 51: 385-397

Cloern JE (2001) Our evolving conceptual model of the coastal eutrophication problem. Mar Ecol Prog Ser 210: 233-253 
Conley D, Carstensen J, Vaquer-Sunyer R, Duarte C (2009) Ecosystem thresholds with hypoxia. Hydrobiologia 629: 21-29

Cook PLM, Revill AT, Clementson LA, Volkman JK (2004) Carbon and nitrogen cycling on intertidal mudflats of a temperate Australian estuary. III. Sources of organic matter. Mar Ecol Prog Ser 280: 55-72

Diaz RJ, Rosenberg R (2008) Spreading Dead Zones and Consequences for Marine Ecosystems. Science 321: 926-929

Dittmar T, Hertkom N, Kattner G, Lara RJ (2006) Mangroves, a major source of dissolved organic carbon to the oceans. Global Biogeochemical Cycles 20: GB1012

Downing JA, McClain M, Twilley R, Melack JM, Elser J, Rabalais NN, Lewis WM, Turner RE, Corredor J, Soto D, Yanez-Arancibia A, Kopaska JA, Howarth RW (1999) The impact of accelerating land-use change on the N-Cycle of tropical aquatic ecosystems: Current conditions and projected changes. Biogeochemistry 46: 109-148

Eyre BD, Ferguson AJP (2002) Comparison of carbon production and decomposition, benthic nutrient fluxes and denitrification in seagrass, phytoplankton, benthic microalgae- and macroalgae- dominated warm-temperate Australian lagoons. Mar Ecol Prog Ser 229: 43-59

Eyre BD, Ferguson AJP (2009) Denitrification efficiency for defining critical loads of carbon in shallow coastal ecosystems. Hydrobiologia 629: 137-146 
Ferrón S, Alonso-Pérez F, Anfuso E, Murillo FJ, Ortega T, Castro CG, Forja JM (2009) Benthic nutrient recycling on the northeastern shelf of the Gulf of Cádiz (SW Iberian Peninsula). Mar Ecol Prog Ser 390: 79-95

Froelich PN (1988) Kinetic control of dissolved phosphate in natural rivers and estuaries: A primer on the phosphate buffer mechanism. Limnol Oceanogr 33: 649-668

Haese RR, Murray EJ, Smith CS, Smith J, Clementson L, Heggie DT (2007) Diatoms control nutrient cycles in a temperate, wave-dominated estuary (southeast Australia). Limnol Oceanogr 52: 2686-2711

Halpern BS, Walbridge S, Selkoe KA, Kappel CV, Micheli F, D'Agrosa C, Bruno JF, Casey KS, Ebert C, Fox HE, Fujita R, Heinemann D, Lenihan HS, Madin EMP, Perry MT, Selig ER, Spalding M, Steneck R, Watson R (2008) A Global Map of Human Impact on Marine Ecosystems. Science 319: 948-952

Herbert RA (1999) Nitrogen cycling in coastal marine ecosystems. FEMS Microbiology Reviews 23: 563-590

Hopkinson CS, Jr (1985) Shallow-water benthic and pelagic metabolism. Mar Biol 87: $19-32$

Howarth R, Sharpley A, Walker D (2002) Sources of nutrient pollution to coastal waters in the United States: Implications for achieving coastal water quality goals. Estuaries and Coasts 25: 656-676

Jennerjahn TC, Ittekkot V, Klopper S, Adi S, Purwo Nugroho S, Sudiana N, Yusmal A, Prihartanto, Gaye-Haake B (2004) Biogeochemistry of a tropical river 
affected by human activities in its catchment: Brantas River estuary and coastal waters of Madura Strait, Java, Indonesia. Estuar Coast Shelf Sci 60: $503-514$

Jickells TD (1998) Nutrient biogeochemistry in the coastal zone. Science 281: 217222

Jones AB, O'Donohue MJ, Udy J, Dennison WC (2001) Assessing Ecological Impacts of Shrimp and Sewage Effluent: Biological Indicators with Standard Water Quality Analyses. Estuar Coast Shelf Sci 52: 91-109

Kana TM, Darkangelo C, Hunt MD, Oldham JB, Bennett GE, Cornwell JC (1994) Membrane Inlet Mass Spectrometer for Rapid High-Precision Determination of N2, O2, and Ar in Environmental Water Samples. Analytical Chemistry 66: $4166-4170$

Kemp WM, Boynton WR, Adolf JE, Boesch DF, Boicourt WC, Brush G, Cornwell JC, Fisher TR, Glibert PM, Hagy JD, Harding LW, Houde ED, Kimmel DG, Miller WD, Newell RIE, Roman MR, Smith EM, Stevenson JC (2005) Eutrophication of Chesapeake Bay: historical trends and ecological interactions. Mar Ecol Prog Ser 303: 1-29

Kemp WM, Sampou P, Caffrey J, Mayer M, Henriksen K, Boynton WR (1990) Ammonium recycling versus denitrification in Chesapeake Bay sediments. Limnol Oceanogr 35: 1545-1563 
Koné YJ-M, Borges AV (2008) Dissolved inorganic carbon dynamics in the waters surrounding forested mangroves of the Ca Mau Province (Vietnam). Estuar Coast Shelf Sci 77: 409-421

Kristensen E, Andersen FØ, Holmboe N, Holmer M, Thongtham N (2000) Carbon and nitrogen mineralization in sediments of the Bangrong mangrove area, Phuket, Thailand. Aquatic Microbial Ecology 22: 199-213

Kristensen E, Flindt MR, Ulomi S, Borges AV, Abril G, Bouillon S (2008) Emission of $\mathrm{CO}_{2}$ and $\mathrm{CH}_{4}$ to the atmosphere by sediments and open waters in two Tanzanian mangrove forests. Mar Ecol Prog Ser 370: 53-67

Mackenzie FT, Ver LM, Lerman A (2002) Century-scale nitrogen and phosphorus controls of the carbon cycle. Chem Geol 190: 13-32

McGlathery KJ, Sundbäck K, Anderson IC (2004) The importance of primary producers for benthic nitrogen and phosphorus cycling. In: Nielsen SL, Banta GT \& Pedersen MF (Eds) Estuarine Nutrient Cycling: The Influence of Primary Producers (pp 231-261). Kluwer Academic Publishers, Dordrecht, The Netherlands

McKinnon AD, Carleton JH, Duggan S (2007) Pelagic production and respiration in the Gulf of Papua during May 2004. Continental Shelf Res 27: 1643-1655

McKinnon AD, Smit N, Townsend S, Duggan S (2006) Darwin Harbour: Water quality and ecosystem structure in a tropical harbour in the early stages of urban development. In: Wolanski E (Ed) The Environment in Asia Pacific Harbours (pp 433-459). Springer, The Netherlands 
McKinnon AD, Trott LA, Brinkman R, Duggan S, Castine S, O'Leary RA, Alongi DM (2010) Seacage aquaculture in a World Heritage Area: The environmental footprint of a Barramundi farm in tropical Australia. Mar Poll Bull 60: 14891501

Nixon S, Ammerman J, Atkinson L, Berounsky V, Billen G, Boicourt W, Boynton W, Church T, Ditoro D, Elmgren R, Garber J, Giblin A, Jahnke R, Owens N, Pilson M, Seitzinger S (1996) The fate of nitrogen and phosphorus at the landsea margin of the North Atlantic Ocean. Biogeochemistry 35: 141-180

Nixon SW (1995) Coastal marine eutrophication: a definition, social causes, and future concerns. Ophelia 41: 199-219

Norrish K, Hutton JT (1969) An accurate X-ray spectrographic method for the analysis of a wide range of geological samples. Geochim Cosmochim Acta 33: $431-453$

Nowicki BL (1994) The Effect of Temperature, Oxygen, Salinity, and Nutrient Enrichment on Estuarine Denitrification Rates Measured with a Modified Nitrogen Gas Flux Technique. Estuar Coast Shelf Sci 38: 137-156

Patrick WH, Jr., Khalid RA (1974) Phosphate Release and Sorption by Soils and Sediments: Effect of Aerobic and Anaerobic Conditions. Science 186: 53-55

Pratihary AK, Naqvi SWA, Naik H, Thorat BR, Narvenkar G, Manjunatha BR, Rao VP (2009) Benthic fluxes in a tropical Estuary and their role in the ecosystem. Estuar Coast Shelf Sci 85: 387-398 
Ram ASP, Nair S, Chandramohan D (2003) Seasonal shift in net ecosystem production in a tropical estuary Limnol Oceanogr 48: 1601-1607

Richardson K, Jørgensen BB (1996) Eutrophication: Definition, History and Effects. In: Jørgensen BB \& Richardson K (Eds) Eutrophication in Coastal Marine Systems (pp 1-19). American Geophysical Union, Washington, DC

Rivera-Monroy V, Madden C, Day J, Twilley R, Vera-Herrera F, Alvarez-Guillén H (1998) Seasonal coupling of a tropical mangrove forest and an estuarine water column: enhancement of aquatic primary productivity. Hydrobiologia 379: 4153

Robertson AI, Daniel PA, Dixon P, Alongi DM (1993) Pelagic biological processes along a salinity gradient in the Fly delta and adjacent river plume (Papua New Guinea). Continental Shelf Res 13: 205-224

Rysgaard S, Christensen PB, Nielsen LP (1995) Seasonal variation in nitrification and denitrification in estuarine sediment colonized by benthic microalgae and bioturbating infauna. Mar Ecol Prog Ser 126: 111-121

Sarma VVSS, Gupta SNM, Babu PVR, Acharya T, Harikrishnachari N, Vishnuvardhan K, Rao NS, Reddy NPC, Sarma VV, Sadhuram Y, Murty TVR, Kumar MD (2009) Influence of river discharge on plankton metabolic rates in the tropical monsoon driven Godavari estuary, India. Estuar Coast Shelf Sci 85: 515-524

Seabergh WC (2006) Hydrodynamics of tidal inlets. In: Vincent L \& Demirbilek Z (Eds) Coastal Engineering Manual, Part II, Coastal Hydrodynamics, Chapter 
6, Engineer Manual 1110-2-110. U.S. Army Corps of Engineers, Washington, DC

Seitzinger SP (1988) Denitrification in freshwater and coastal marine ecosystems: ecological and geochemical significance. Limnol Oceanogr 33: 702-724

Sloth NP, Blackburn H, Hansen LS, Risgaard-Petersen N, Lomstein BA (1995) Nitrogen cycling in sediments with different organic loading. Mar Ecol Prog Ser 116: 163-170

Sloth NP, Riemann B, Nielsen LP, Blackburn T (1996) Resilience of Pelagic and Benthic Microbial Communities to Sediment Resuspension in a Coastal Ecosystem, Knebel Vig, Denmark. Estuar Coast Shelf Sci 42: 405-415

Soetaert K, Middelburg J (2009) Modeling eutrophication and oligotrophication of shallow-water marine systems: the importance of sediments under stratified and well-mixed conditions. Hydrobiologia 629: 239-254

Sokal RR, Rohlf FJ (1995) Biometry, 3rd ed. WH Freeman and Company, New York

Ståhlberg C, Bastviken D, Svensson BH, Rahm L (2006) Mineralisation of organic matter in coastal sediments at different frequency and duration of resuspension. Estuar Coast Shelf Sci 70: 317-325

Trott LA, Alongi DM (1999) Variability in surface water chemistry and phytoplankton biomass in two tropical, tidally dominated mangrove creeks. Mar Freshwater Res 50: 451-457 
Trott LA, McKinnon AD, Alongi DM, Davidson A, Burford MA (2004) Carbon and nitrogen processes in a mangrove creek receiving shrimp farm effluent. Estuar Coast Shelf Sci 59: 197-207

Wainright SC, Hopkinson CS (1997) Effects of sediment resuspension on organic matter processing in coastal environments: A simulation model. Journal of Marine Systems 11: 353-368

Webster IT, Harris GP (2004) Anthropogenic impacts on the ecosystems of coastal lagoons: modelling fundamental biogeochemical processes and management implications. Mar Freshwater Res 55: 67-78

Williams D, Wolanski E, Spagnol S (2006) Hydrodynamics of Darwin Harbour. In: Wolanski E (Ed) The Environment in Asia Pacific Harbours (pp 461-476). Springer, The Netherlands

Wolanski E, Jones M, Bunt JS (1980) Hydrodynamics of a tidal creek-mangrove swamp system. Mar Freshwater Res 31: 431-450

Wolanski E, Mazda Y, Ridd P (1992) Mangrove hydrodynamics. In: Robertson AI \& Alongi DM (Eds) Tropical Mangrove Ecosystems (pp 43-62). American Geophysical Union, Washington, D.C.

Wolanski E, Spagnol S, Thomas S, Moore K, Alongi DM, Trott L, Davidson A (2000) Modelling and Visualizing the Fate of Shrimp Pond Effluent in a Mangrove-fringed Tidal Creek. Estuar Coast Shelf Sci 50: 85-97 
Woodroffe CD, Bardsley KN, Ward PJ, Hanley JR (1988) Production of mangrove litter in a macrotidal embayment, Darwin Harbour, N.T., Australia. Estuar Coast Shelf Sci 26: 581-598

Zar JH (1999) Biostatistical Analysis, 4th edn. Prentice Hall, NJ. 
Table 1: Flushing times $(T)$ calculated using model parameters for the tidal creeks. $\mathrm{RC}=$ reference creek; $\mathrm{MC}=\mathrm{Myrmidon}$ Creek; $\mathrm{BC}=\mathrm{Buffalo}$ Creek; $L=$ length, $W=$ width, $A(b)=$ water area, $V=$ water volume, $a(b)=$ tidal amplitude, $e=$ exchange efficiency, $p=$ tidal prism. Creek dimensions (were estimated from satellite imagery, mean water depth was estimated from field measurements at the sampling sites, tidal amplitude $(a(b))$ was estimated from tide charts, and $e$ was estimated from creek morphology. $\mathrm{BC} 1$ and $\mathrm{BC} 3$ were calculated separately due to the decreased $e$ value upstream as a result of the meandering nature of the creek. Note: all parameters are estimates only.

\begin{tabular}{lcccc}
\hline Model Parameter & RC1 & MC1 & BC3 & BC1 \\
\hline$L(\mathrm{~m})$ & 1500 & 1000 & 500 & 2500 \\
$W(\mathrm{~m})$ (at mouth) & 300 & 250 & 75 & 75 \\
$W(\mathrm{~m})$ (at site) & 150 & 100 & 40 & 10 \\
$A(b)\left(\mathrm{m}^{2}\right)$ & 337,500 & 175,000 & 28,750 & 106,250 \\
Mean Water Depth $(\mathrm{m})$ & 4 & 4 & 3 & 3 \\
$V\left(\mathrm{~m}^{3}\right)$ & $1,350,000$ & 700,000 & 86,250 & 318,750 \\
$a(b)(\mathrm{m})$ (spring tide) & 5.0 & 5.0 & 4.0 & 3.0 \\
$a(b)(\mathrm{m})$ (neap tide) & 2.0 & 2.0 & 1.5 & 1.0 \\
$e$ & 1 & 1 & 0.5 & 0.2 \\
$p($ spring) & $3,375,000$ & $1,750,000$ & 230,000 & 637,500 \\
$p($ neap) & $1,350,000$ & 700,000 & 86,250 & 212,500 \\
$T(\mathrm{~d})$ (spring) & 0.3 & 0.3 & 0.5 & 1.6 \\
$T(\mathrm{~d})$ (neap) & 0.6 & 0.6 & 1.3 & 4.8 \\
\hline
\end{tabular}


Table 2: Mean $( \pm \mathrm{SD})$ physico-chemical parameters in the water column in three tidal creeks in Darwin Harbour during the sampling periods. *DIN:phosphate ratio $\left(\mathrm{NH}_{4}+\mathrm{NO}_{\mathrm{x}}: \mathrm{PO}_{4}\right)^{\dagger} \mathrm{MC}-\mathrm{S}$ values are the mean of all samples collected from the sewage effluent plume in MC across all three field surveys. Oct-07 = dry season; Mar-08 = wet season, Dec-08 = dry season

\begin{tabular}{|c|c|c|c|c|c|c|}
\hline \multirow[t]{2}{*}{ Variable } & \multicolumn{2}{|c|}{ Reference Creek } & \multicolumn{3}{|c|}{ Myrmidon Creek } & \multirow{2}{*}{$\begin{array}{c}\text { Buffalo Creek } \\
\text { Dec-08 }\end{array}$} \\
\hline & Oct-07 & Mar-08 & Oct-07 & Mar-08 & MC-S ${ }^{\dagger}$ & \\
\hline Water temperature & $31.4(0.5)$ & $29.4(0.6)$ & $30.3(0.8)$ & $29.9(0.7)$ & $32.1(1.1)$ & $30.7(2.0)$ \\
\hline Salinity & $37.0(0.3)$ & $22.5(3.5)$ & $36.5(0.4)$ & $29.3(1.3)$ & $28.2(7.7)$ & $20.6(10.0)$ \\
\hline Suspended solids & $17.1(3.5)$ & $12.3(4.6)$ & $15.8(5.6)$ & $28.3(5.5)$ & $116.2(40.1)$ & 97.7 (131.3) \\
\hline DO saturation (\%) & $85.8(10.3)$ & $77.6(9.4)$ & $84.7(9.4)$ & $86.2(8.2)$ & $69.1(14.8)$ & $43.3(25.2)$ \\
\hline $\begin{array}{l}\text { DO concentration } \\
\left(\mathrm{mg} \mathrm{l}^{-1}\right)\end{array}$ & $5.1(0.6)$ & $5.2(0.6)$ & $5.2(0.5)$ & $5.5(0.5)$ & $4.3(0.8)$ & $2.9(1.8)$ \\
\hline Euphotic depth (m) & $5.2(2.1)$ & 3.7 (1.3) & $5.9(1.9)$ & $3.8(0.3)$ & $3.0(0.6)$ & $1.6(0.8)$ \\
\hline Chl $a\left(\mu \mathrm{gl}^{-1}\right)$ & $1.8(0.4)$ & $2.3(0.2)$ & $2.8(1.3)$ & $1.7(0.04)$ & $9.9(3.8)$ & $90.0(37.6)$ \\
\hline $\mathrm{NH}_{4}(\mu \mathrm{M})$ & $0.15(0.09)$ & $1.11(0.36)$ & $0.15(0.17)$ & $0.33(0.11)$ & $12.4(10.4)$ & $35.5(24.2)$ \\
\hline $\mathrm{NO}_{\mathrm{x}}(\mu \mathrm{M})$ & $0.13(0.13)$ & $0.77(0.40)$ & $0.07(0.06)$ & $0.27(0.21)$ & $6.5(6.7)$ & $14.1(10.2)$ \\
\hline $\mathrm{PO}_{4}(\mu \mathrm{M})$ & $0.21(0.07)$ & $0.15(0.02)$ & $0.14(0.13)$ & $0.13(0.03)$ & $5.8(8.3)$ & $7.2(4.9)$ \\
\hline $\mathrm{SiO}_{4}(\mu \mathrm{M})$ & $10.6(4.4)$ & $26.4(2.3)$ & $4.4(3.8)$ & $5.7(0.8)$ & $49.6(34.2)$ & $38.4(21.4)$ \\
\hline Molar N:P ratio* & $1.3(0.4)$ & $12.5(3.7)$ & $1.4(0.7)$ & $4.5(2.2)$ & $6.4(4.6)$ & $8.4(4.9)$ \\
\hline
\end{tabular}


Table 3: Surface sediment characteristics at the upstream and downstream sites in three tidal creeks in Darwin Harbour

\begin{tabular}{|c|c|c|c|c|c|c|c|c|c|c|}
\hline Site & $\begin{array}{c}\mathrm{chl} \mathrm{a} \\
\left(\mathrm{mg} \mathrm{m}^{-2}\right)\end{array}$ & Porosity & \%TOC & $\% \mathrm{~N}$ & $\delta^{13} \mathrm{C} \%$ & $\delta^{15} \mathrm{~N} \%$ & TP $\mathrm{mg} \mathrm{kg}^{-1}$ & $\begin{array}{c}\text { C:N } \\
\text { (mol:mol) }\end{array}$ & $\begin{array}{c}\mathrm{N}: \mathrm{P} \\
\text { (mol:mol) }\end{array}$ & $\begin{array}{c}\text { C:P } \\
\text { (mol:mol) }\end{array}$ \\
\hline RC1 dry & 37 & 81.9 & 4.6 & 0.22 & -24.9 & 3.7 & 583 & 24.1 & 8.4 & 203 \\
\hline $\mathrm{RC} 1$ wet & 34 & 83.2 & 3.5 & 0.29 & -25.7 & 4.2 & 628 & 13.8 & 10.3 & 142 \\
\hline RC2 dry & 17 & 74.4 & 2.6 & 0.15 & -25.0 & 4.1 & 478 & 20.5 & 7.0 & 143 \\
\hline $\mathrm{RC} 2$ wet & 41 & 76.5 & 3.9 & 0.17 & -25.1 & 4.1 & 559 & 26.6 & 6.8 & 181 \\
\hline MC3 dry & 31 & 72.0 & 1.8 & 0.13 & -23.5 & 2.7 & 646 & 16.3 & 4.5 & 73 \\
\hline MC3 wet & 42 & 75.5 & 1.8 & 0.08 & -24.7 & 2.3 & 635 & 27.5 & 2.7 & 73 \\
\hline MC1 dry & 60 & 78.8 & 3.0 & 0.22 & -25.0 & 6.6 & 825 & 15.7 & 5.9 & 93 \\
\hline MC1 wet & 50 & 80.7 & 2.4 & 0.22 & -25.6 & 6.9 & 762 & 12.7 & 6.4 & 82 \\
\hline BC3 & 161 & 78.7 & 2.8 & 0.28 & -23.3 & 8.8 & 997 & 11.6 & 6.3 & 73 \\
\hline $\mathrm{BC} 1$ & 532 & 83.3 & 4.5 & 0.42 & -25.3 & 12.6 & 1363 & 12.8 & 6.7 & 86 \\
\hline
\end{tabular}


Table 4: Results of 2-way ANOVA tests comparing pelagic and benthic processes in MC and RC during the dry and wet seasons. Significant differences are highlighted in bold.

\begin{tabular}{|c|c|c|c|c|c|}
\hline Process & $\alpha$ & Season & Site & Interaction & Post-hoc results \\
\hline $\mathrm{P}_{\max }$ & 0.05 & 0.5240 & 0.2227 & 0.0002 & Significantly higher at MC1dry and MC3 wet \\
\hline Respiration & 0.05 & 0.4736 & 0.6497 & 0.2032 & \\
\hline fDIC & 0.05 & 0.1420 & 0.9125 & 0.3960 & \\
\hline fDO & 0.05 & 0.2561 & 0.8792 & 0.2039 & \\
\hline $\mathrm{NHH} 4$ & 0.05 & 0.1160 & 0.6235 & 0.4376 & \\
\hline ANOx & 0.01 & 0.0347 & 0.0006 & 0.7339 & Significantly higher at $\mathrm{MC} 1$ \\
\hline AN2 & 0.05 & 0.7671 & 0.8993 & 0.7911 & \\
\hline benthic PP & 0.01 & 0.6238 & 0.0222 & 0.0186 & \\
\hline chl a & 0.01 & 0.1487 & 0.0378 & 0.0330 & \\
\hline
\end{tabular}


Table 5: Comparison of pelagic (net primary production and community respiration, mmol $\mathrm{C} \mathrm{m}^{-2} \mathrm{~d}^{-1}$ ) and benthic (respiration, ammonia and phosphate fluxes, $\mathrm{mmol} \mathrm{m}^{-2} \mathrm{~d}^{-1}$ as $\mathrm{C}, \mathrm{N}$, and P respectively) processes in tropical estuaries and coastal systems.

\begin{tabular}{|c|c|c|c|c|c|c|c|}
\hline Estuary/Coastal System & Sampling location & $\begin{array}{l}\text { Pelagic } \\
\text { Primary } \\
\text { Production }\end{array}$ & $\begin{array}{l}\text { Pelagic } \\
\text { Respiration }\end{array}$ & $\begin{array}{l}\text { Benthic } \\
\text { Respiration }\end{array}$ & $\begin{array}{l}\text { Benthic N } \\
\text { flux }\end{array}$ & $\begin{array}{l}\text { Benthic P } \\
\text { flux }\end{array}$ & Reference \\
\hline Buffalo Creek & Tidal creek & $131-249$ & $217-671$ & $271-391$ & $22-45$ & $1.5-15$ & This study \\
\hline Myrmidon \& Reference Creeks & Tidal creeks & $8-16$ & $50-94$ & $65-92$ & $0.32-1.12$ & $0.06-0.23$ & This study \\
\hline Darwin Harbour, Australia & Estuary & $82-180$ & & $65-74^{*}$ & $3.5-8.2$ & $0.05-0.1$ & \\
\hline Darwin Harbour, Australia & Shallow margins & $31-53$ & $43-88$ & 77 & 0 & -0.005 & 1 \\
\hline Port Douglas, Australia & Tidal creeks & $39-277$ & & & $0.9-2.1$ & $-0.02--0.06$ & 2 \\
\hline Fly River Delta, PNG & Coastal waters & $11-58$ & $0.5-3$ & & & & 3 \\
\hline Mandovi \& Zuari estuary, India & Estuary & $23-155$ & $42-468$ & & & & 4 \\
\hline Gautami-Godavari estuary, India & Estuary & $-108-124$ & $16-1503$ & & & & 5 \\
\hline Hinchinbrook Channel, Australia & Tidal creeks & $5-30$ & $50-75$ & & & & 6 \\
\hline Terminos Lagoon, Gulf of Mexico & Tidal channel & $2.5-542$ & & & & & 7 \\
\hline Gulf of Papua, PNG & Coastal waters & $13-52$ & $59-135$ & & & & 8 \\
\hline Mandovi Estuary, India & Estuary & & & $35-99^{*}$ & $0.8-5.2$ & $0.13-0.25$ & 9 \\
\hline Northern Queensland, Australia & $\begin{array}{l}\text { Tidal creek, shrimp } \\
\text { pond }\end{array}$ & & & & $11.3-45.8$ & $0-0.58$ & 10 \\
\hline Phuket Island, Thailand & Mangrove forest & & & $32-62$ & $-2.2-1.74$ & & 11 \\
\hline Peninsular Malaysia & Mangrove forest & & & $11-79$ & $-0.25--0.44$ & & 12 \\
\hline Hinchinbrook Channel, Australia & Mangrove forest & & & $14-22$ & & & 13 \\
\hline Gulf of Thailand & Mangrove forest & & & $5-73$ & & & 14 \\
\hline
\end{tabular}

${ }^{1}$ Burford et al. (2008); ${ }^{2}$ Trott et al. (2004); ${ }^{3}$ Robertson et al. (1993); ${ }^{4}$ Ram et al. (2003); ${ }^{5}$ Sarma et al. (2009); ${ }^{6}$ McKinnon et al. (2010); ${ }^{\prime}$ Rivera-Monroy et al. (1998); ${ }^{8}$ McKinnon et al. (2007); ${ }^{9}$ Pratihary et al. (2009); ${ }^{10}$ Burford \& Longmore (2001); ${ }^{11}$ Kristensen et al. (2000); ${ }^{12}$ Alongi et al. (2004); ${ }^{13}$ Alongi et al. (1999b); ${ }^{14}$ Alongi et al. (2001) 


\section{Figure Captions}

Fig. 1: Map of Darwin Harbour, Australia showing the three tidal creeks and sampling sites in: a) Reference Creek, b) Myrmidon Creek and c) Buffalo Creek

Fig. 2: Mean dry season benthic fluxes $\left(\mathrm{mmol} \mathrm{m}^{-2} \mathrm{~d}^{-1}\right)$, denitrification efficiency $(\%)$, water column primary production (Pmax) and respiration $\left(\mathrm{mmol} \mathrm{m}^{-3} \mathrm{~h}^{-1}\right)$ in $\mathrm{RC}, \mathrm{MC}$ and $\mathrm{BC}$. Error bars $=\mathrm{SE}$ of replicate samples. n.d. = no data.1-way ANOVA results are shown ( $\mathrm{p}$-values) with significant differences highlighted in bold (adjusted $\alpha=$ 0.02532, unless otherwise stated). Sites which are significantly different (as identified in post hoc comparisons) indicated as sd.

Fig. 3: Mean benthic and pelagic respiration and primary productivity. Error bars = SE of replicate samples. 1-way ANOVA results are shown (p-values) with significant differences highlighted in bold (adjusted $\alpha$ also shown). Sites which are significantly different (as identified in post hoc comparisons) indicated as sd.

Fig. 4: Vector diagram (A) indicating he loadings on PCA1 and PC2 and biplot of sites (B). Closed symbols = dry season; open symbols = wet season

Fig. 5: Plot showing the relative impact on a) water quality parameters, b) pelagic processes, c) sediment parameters and d) benthic processes at each site compared to RC. Values for each site were calculated by dividing the mean rates and concentrations of each variable by the mean rates and concentrations measured in RC. Data from the dry and wet season were averaged for these calculations. Note the different $y$-axis scale in $d$ ). 
Figure 1

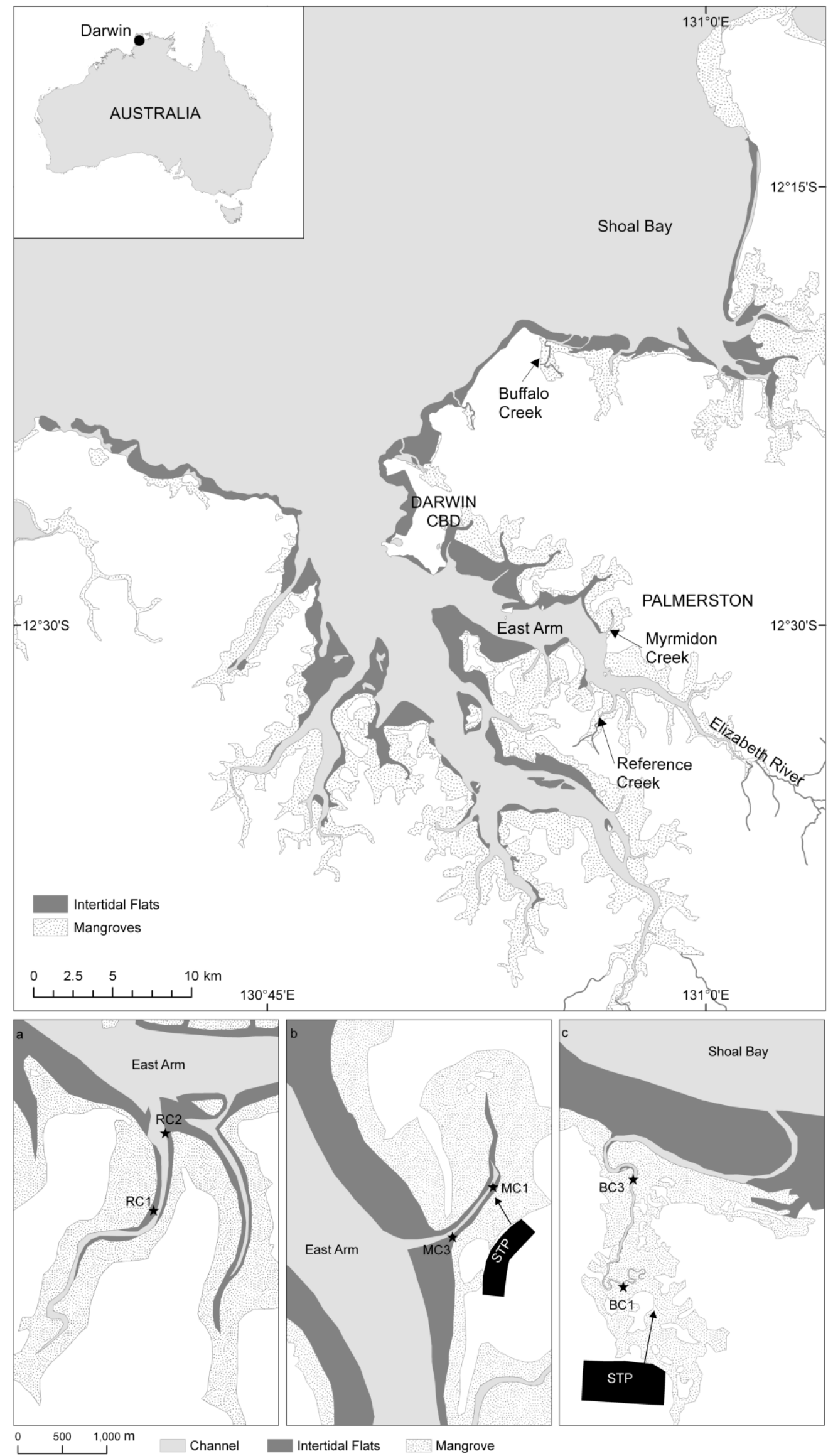


Figure 2
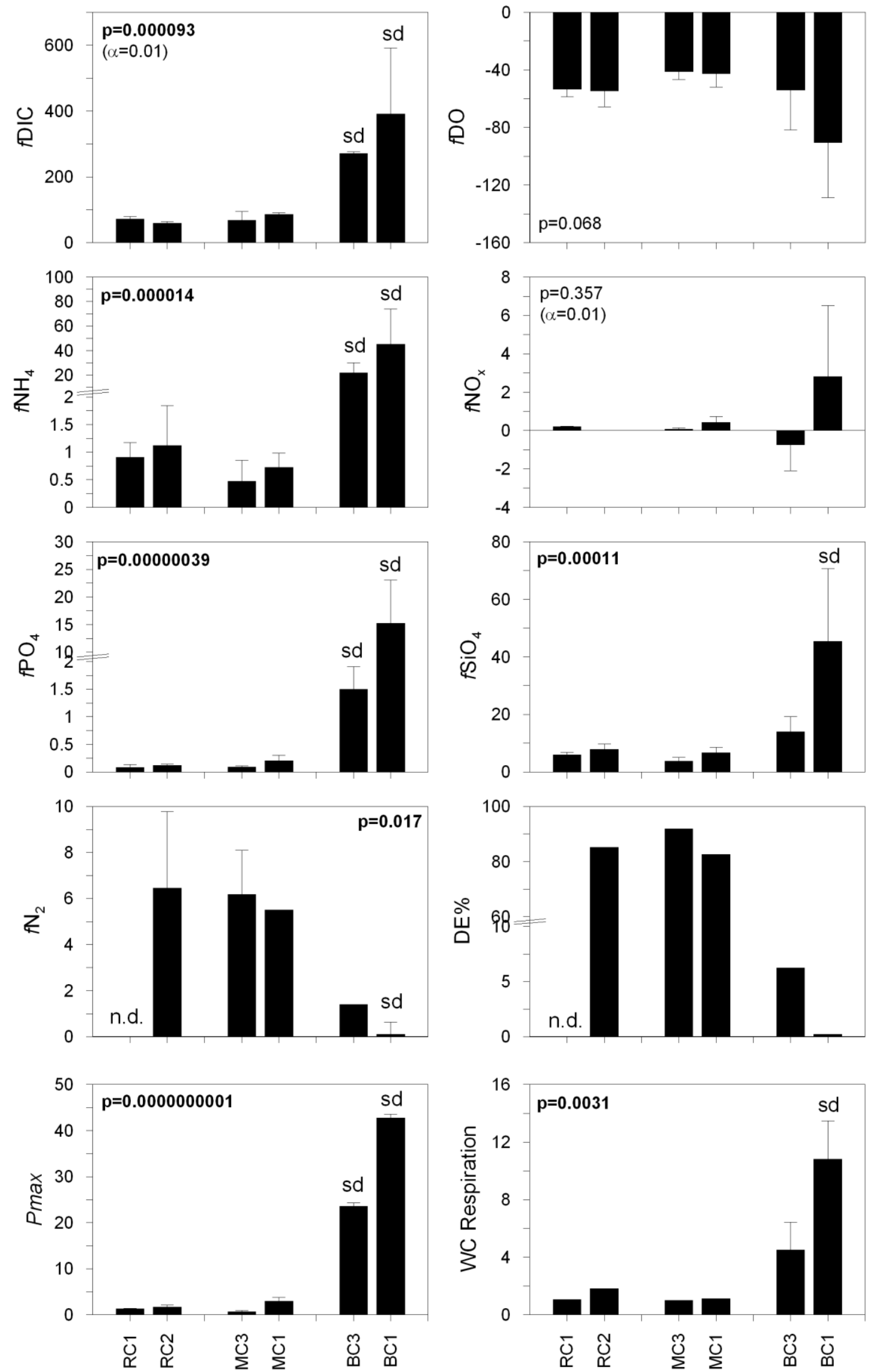
Figure 3
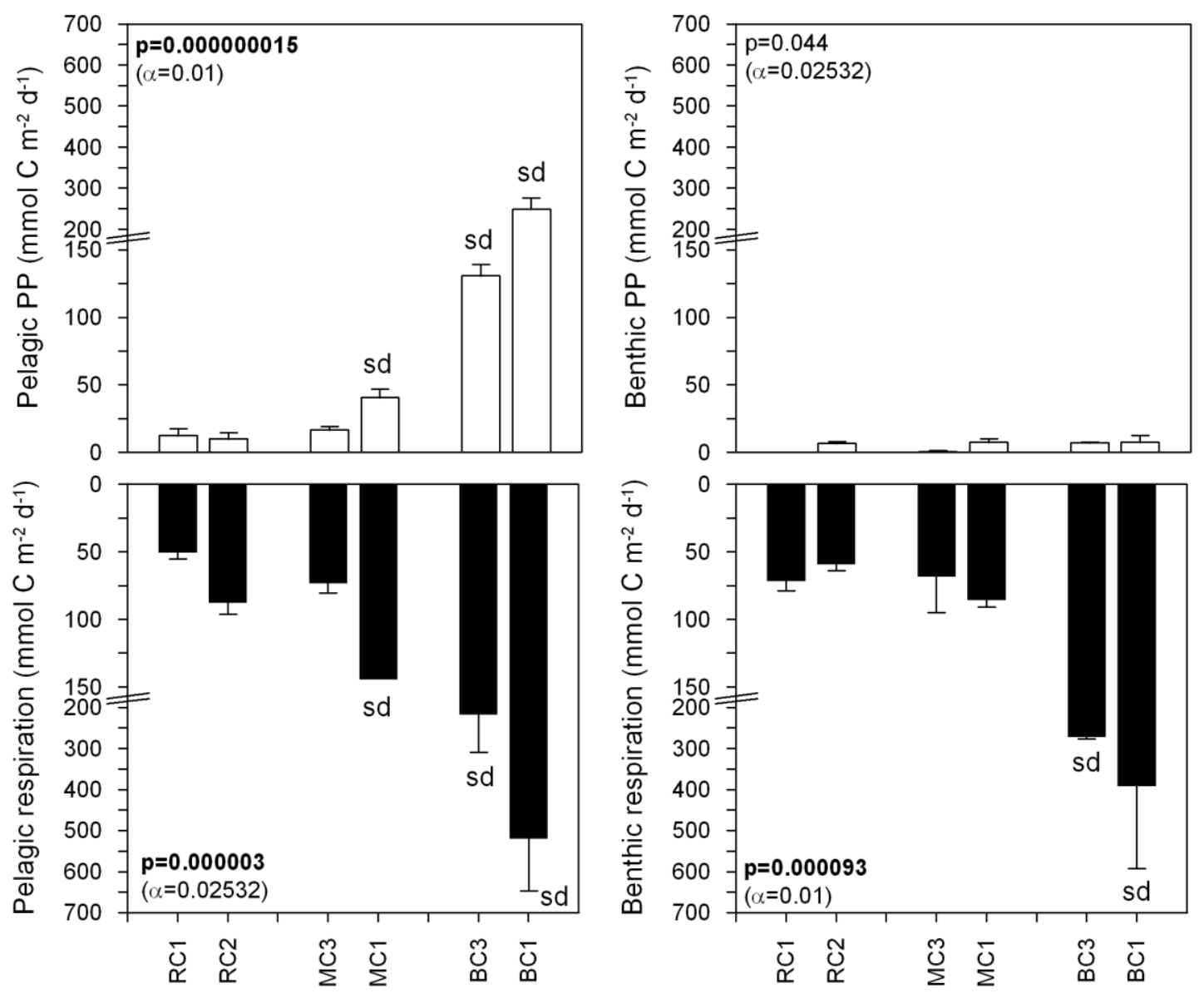
Figure 4
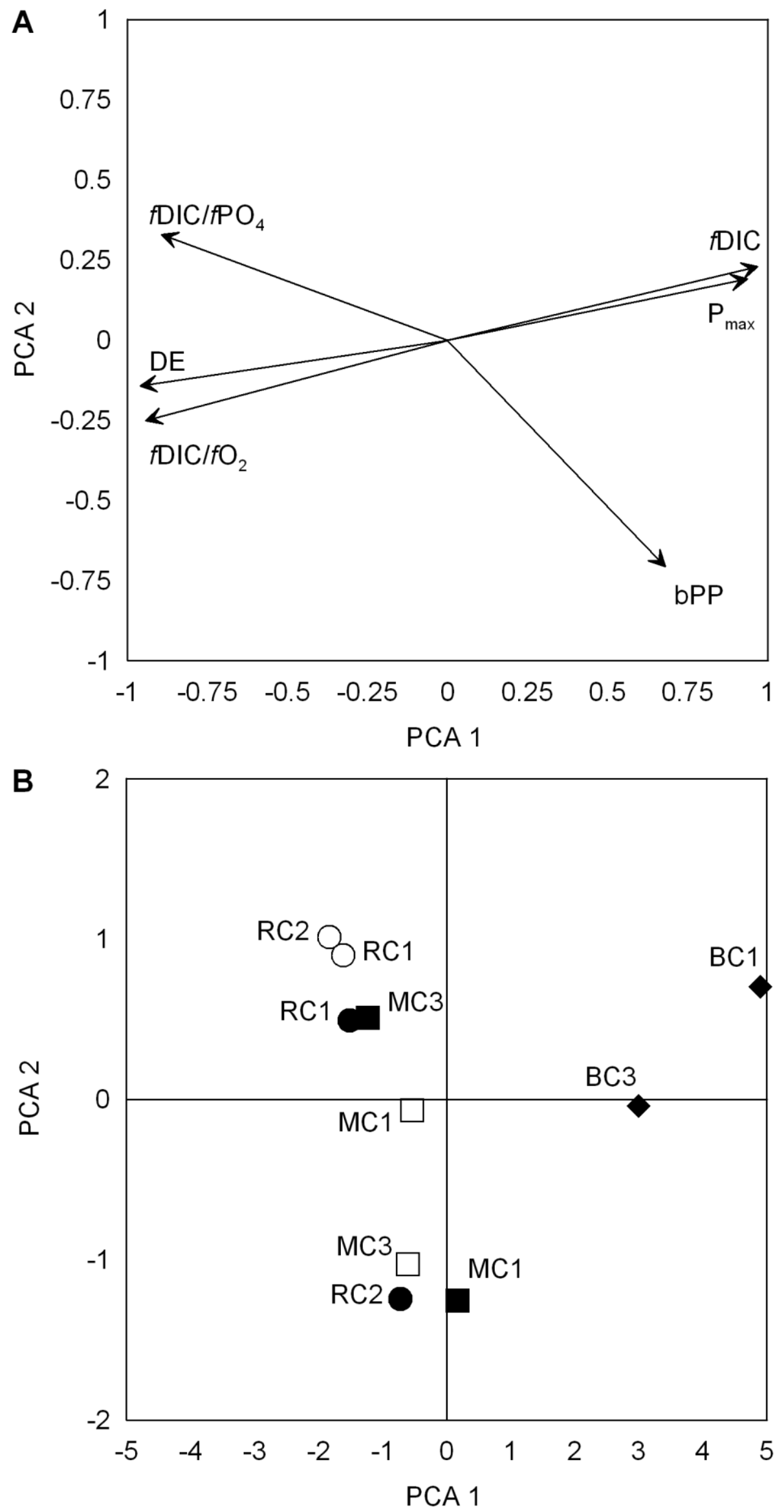
Figure 5
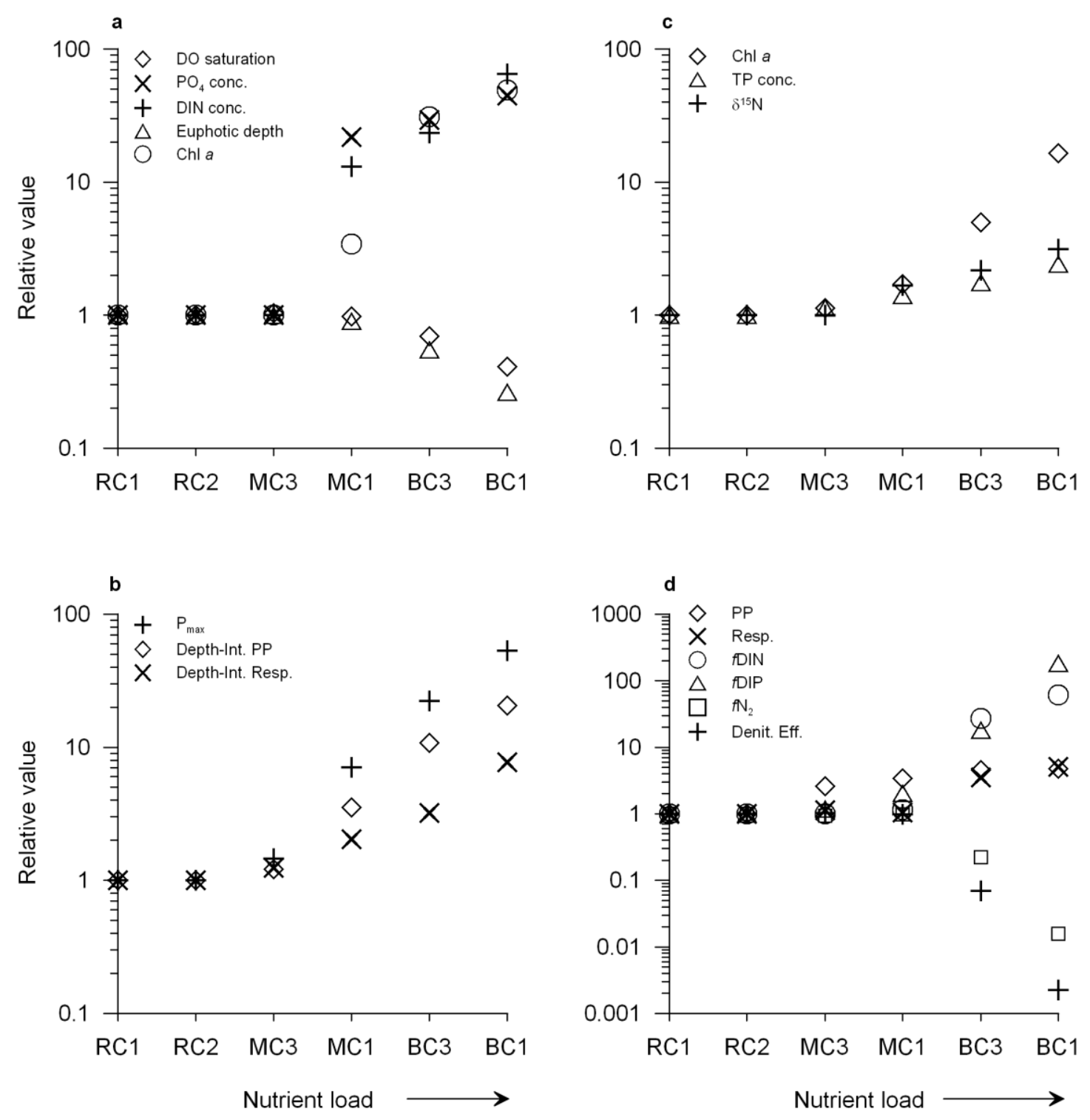